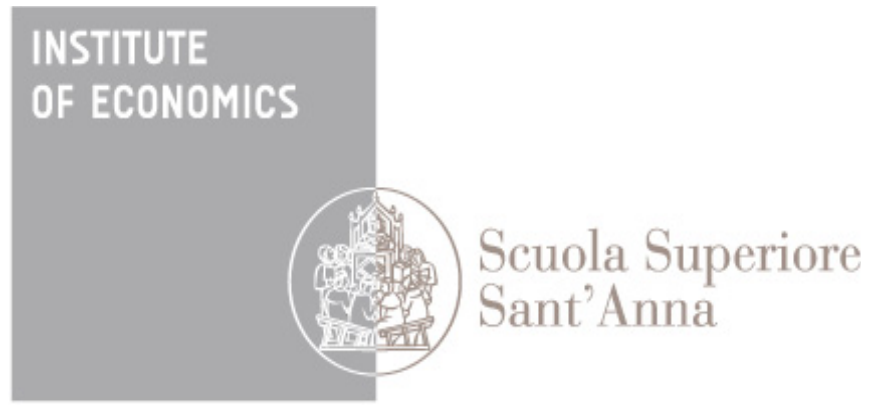

LEM | Laboratory of Economics and Management

Institute of Economics

Scuola Superiore Sant'Anna

Piazza Martiri della Libertà, 33 - 56127 Pisa, Italy ph. +3905088.33 .43$

institute.economics@sssup.it

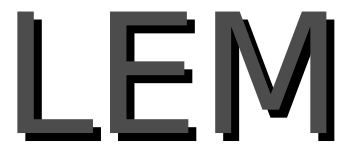

Working Paper Series

\title{
The Role of Comparative Advantage, Endowments and Technology in Structural Transformation
}

\author{
Giovanni Dosi a \\ Matteo Tranchero ${ }^{b}$
}

a Institute of Economics \& Department EMbeDS, Scuola Superiore Sant'Anna, Pisa, Italy. ${ }^{\mathrm{b}}$ Haas School of Business, UC Berkeley, USA.

\section{8/33}

ISSN(ONLINE) 2284-0400 


\title{
The Role of Comparative Advantage, Endowments and Technology in Structural Transformation*
}

\author{
Giovanni Dosi ${ }^{\mathrm{a}}$ and Matteo Tranchero ${ }^{\mathrm{b}}$ \\ aScuola Superiore Sant'Anna, Pisa, Italy \\ ${ }^{\mathrm{b}}$ Haas School of Business, UC Berkeley, USA
}

July 29, 2019

\begin{abstract}
In this chapter we discuss the role of natural resources and endowment structures on structural change. Departing from theories of trade that stress specialization according to one's comparative advantages as the key route to development, we articulate an alternative point of view on the role of technological learning and absolute advantages for structural transformation. Ricardian adjustment processes relying on endowment-based comparative advantages are often times a misleading driver of development; rather, competitiveness offers a better criterion to achieve sustained economic well-being. This theoretical perspective provides useful guidance to interpret the effects of unbridled globalization and the role of natural resources relative to industrial and trade policies in shaping the process of structural change and economic development.
\end{abstract}

Keywords: structural change; endowments and trade; technological gaps; catching-up. JEL Code: O14, O33, F43

\footnotetext{
${ }^{*}$ Acknowledgements: We are indebted to Eddy Szirmai, Ludovico Alcorta, Neil Foster-McGregor, Bart Verspagen, Marco Vivarelli, Nelson Barbosa and participants to the workshop "New Perspectives on Structural Change: Causes and Consequences of Structural Change in the Global Economy" (Maastricht, February 2018) and to the INET-YSI Regional Convening (Trento, June 2018) for insightful discussions and useful comments. We acknowledge the support from the ISIGrowth project on Innovation-fuelled, Sustainable, Inclusive Growth which received funding from the European Union Horizon 2020 research and innovation program under grant agreement No. 649186 ISIGrowth.
} 


\section{Introduction}

One of the most dramatic structural changes witnessed by developed economies has been the sharp decline of employment in the primary sector (mainly agriculture, but also extraction of commodities). In 1840, about two thirds of US workers worked in the primary sector; at the turn of the new millennium, this share had fallen to just $2.4 \%$ (Jones, 2016). Still, the common wisdom is that natural resource endowments and the related comparative advantages in trade are an important ingredient for prosperity and development. In such a perspective, trade benefits all its participants, and comparative advantages shape international specialization patterns giving rise to globally efficient outcomes. Unfortunately, all that glitters is not gold.

Back in 1613, Antonio Serra investigated and discussed why the Republic of Venice was much richer than the Kingdom of Naples, despite having no comparable natural resources (Serra 1613; Reinert 1999). When Serra was writing, Venice was probably one of the richest places in the world, with a florid industrial production specialized in high value added manufacture (e.g. glass) exported on foreign markets; Naples, on the contrary, was a rather backward country in spite of the fertile lands and abundance of raw materials. Although with rudimentary instruments and a mercantilistic approach, Serra found the answer to the puzzle in the different patterns of industrial and trade specialization of the two countries. The key insight is that the gap in wealth levels between Venice and Naples resides in the very difference between primary and industrial activities: while the latter enjoy what we would now call increasing returns, the former do not allow similar long-term wealth generation and eventually incur in decreasing returns to scale (Reinert 1996; see also the Chapter by Porcile).

In the present essay, we shall try to answer the very same question of Antonio Serra in light of the recent waves of trade liberalization and globalization that unfolded since the 1980s. We shall argue that endowment-based comparative advantages often turn out to be misleading drivers of economic development. This has been historically true and we argue that it continues to be so also in the era of globalization. We will outline a theoretical basis to discuss the role of natural endowments visá-vis technology in structural transformation and to interpret the most recent evidence. The role of technological learning and absolute advantages, as well as the relevance of industrial and trade policies to achieve successful development will be extensively discussed. 


\section{International Trade, Comparative Advantages and Structural Change}

\subsection{Natural Resources in Economic and Trade Theories}

The traditional theory of trade has its intellectual roots in the seminal work of Ricardo (1817) and later Heckscher (1919) and Ohlin (1933), all the way to the recent contributions that are known as "New Trade Theory" (Krugman 1979, Krugman 1980) and "New-New Trade Theory" (Melitz and Trefler, 2012). Broadly speaking, this entire family of trade theories identifies the main determinant of trade flows in the law of comparative advantages, first showed by Ricardo with a famous numerical example of two countries (England and Portugal) and two goods (cloth and wine), both produced by a certain fixed amount of the same factor of production (labour). The standard trade wisdom goes as follow: given the usual assumptions on technology, demand, perfect competition and market clearing, each country will do better when it specializes in the production of different goods and it engages in international exchanges; remarkably, Ricardo actually proved that this is true even when one country has an absolute advantage in the production of every good (Gandolfo, 2013).

In the original contribution of Ricardo (1817), inter-country technological differences as reflected in labour productivity differentials were the source of comparative advantage. However, economic analyses usually rely on generalizations and refinements of the Heckscher-Ohlin model (Flam and Flanders, 1991). This type of models underlie a factor proportions theory of comparative advantages according to which international specialization stems from different endowments structures. Said otherwise, natural resource endowments such as oilfields or fertile soils ultimately determine the patterns of international trade 1 Recent contributions have relaxed some hypotheses or changed the source of comparative advantage $2^{2}$ but the reliance on comparative advantages is still the cornerstone of

\footnotetext{
${ }^{1}$ Notably, this class of theories does not provide an ad hoc treatment of cheap labour endowments. If anything, abundance of unskilled workforce if treated precisely as any other possible commodity endowments, leading to the analogue prescription of specializing in labour-intensive low-technology manufacturing activities (see for instance Lin 2011). And even if the workforce is intrinsically able to learn new skills through learning-by-doing, this fact per se is not enough to automatically climb the development ladder. As an example, consider the Mexican maquila-type assembly lines producing for the US market, that in the absence of suitable policies, have not been able to bring countrywide technological upgrading (Cimoli and Katz, 2003).

${ }^{2}$ Starting in the 1970s, New Trade Theory introduced economies of scale to relax a standard assumptions on the production function (Krugman, 1987). This class of models places the microfoundations of intra-industry trade in the strategic behaviours of firms operating in conditions of monopolistic competition due to assumptions of "love of variety" and product differentiation (Krugman 1980 Grossman and Helpman 1989). New Trade Theory posits that comparative advantages stemming from economies of scale and the market structure, more than natural resource endowments, give rise to international trade. More recently, general equilibrium theories of trade have been expanded in two directions. On the one hand, New-New Trade Theory has dropped the assumption of the representative firm: in these models, firms differ in their productivity levels and only the most productive ones engage in international trade (Melitz 2003. Bernard et al. 2007). On the other hand, "Neo-Ricardians" revamped the study of comparative advantages in the spirit of Ricardo by means of structural general equilibrium models (Eaton and Kortum 2002; Eaton and Kortum 2012). These models adopt a probabilistic representation of technologies as random draws from extreme value or Poisson distributions in order to keep the model tractable and reflect the empirical evidence; however, this modelling choice prevents the exploration of the origins and evolution of inter-country technology gaps.
} 
neoclassical trade theory.

Despite their analytic elegance, trade theories inspired by Ricardo tend to share some conceptual limitations when applied to structural change in developing countries. First, they neglect the dynamics of trade-induced structural specialization and, second, they espouse a semi-Panglossian optimism in the optimality of the trade equilibrium (Samuelson, 2004), mainly due to the hypothesis of fullutilization of resources 3 Consider the case of natural resource endowments. The historical record has consistently showed a widespread underperformance of economic growth in resource-rich economies (Sachs and Warner 1995; Auty 1983, Van der Ploeg 2011; Venables 2016). It is a striking fact that many of the poorest countries in the world are also the richest in oil or other natural resources, even after controlling for many potential alternative explanations (Sachs and Warner, 2001). This finding, which is not only inconsistent with conventional trade theories but it also seems to go against what common sense would suggest. $4^{4}$ was dubbed "natural resource curse" in a classic book by Auty (1983). In Table 1 we provide a selected review of the principal mechanisms proposed to explain the empirical evidence.

Among the plausible mechanisms, two are particularly tied to the issues of structural change and trade. Back in the 1980s, some economists studied the peculiar case of the Netherlands after the discovery of the Groningen gas field (Corden and Neary 1982; Corden 1984). After the discovery, two phenomena were observed. On the one hand, increased wealth changed the international balance of payments and induced an appreciation of the local currency vis-á-vis the foreign ones, with strong negative effects on domestic manufacturing producers. On the other hand, the booming commodity sector required new workforce, with the result of both raising wages and drawing workers away from tradable industries. Note however that, given the generally low labour-intensity of modern extraction activities, the latter "direct deindustrialization" mechanism is of smaller magnitude when compared with the "indirect deindustrialization" mechanisms operating via international trade (Corden, 1984). As a consequence, the increase of extractive activities crowded out production of tradable goods, a phenomenon eloquently named "Dutch Disease" since then (Torvik 2009; Van der Ploeg 2011). Relatedly, the contraction of the manufacturing sector can induce a loss of growth in dynamic terms. Many studies document how the manufacturing sector constitutes the true engine of growth due to

\footnotetext{
${ }^{3}$ However, the recent empirical contributions on the impact of trade on local labour markets (e.g. Autor et al. 2013 Pierce and Schott 2016) are leading to much less optimistic assessments (Autor et al., 2016).

${ }^{4}$ "The first to suggest that countries can profit from their endowments was indeed Adam Smith (1776) with his "vent for surplus" theory: poor countries can export under-used natural resources which are highly valued abroad, thus generating economic rents. However, economic research has later shown that other more subtle mechanisms are at play when dealing with exports of natural resources.
} 
Table 1: List of the main causal mechanisms explaining the "natural resource curse"

\begin{tabular}{|c|c|}
\hline Mechanism & Description \\
\hline $\begin{array}{l}\text { Prebisch-Singer } \\
\text { hypothesis }\end{array}$ & $\begin{array}{l}\text { Specialization in production of natural resources weakens growth because manufactured goods have a greater income } \\
\text { elasticity of demand than primary products: as incomes rise, the demand for manufactured goods increases more } \\
\text { rapidly than demand for primary products. In addition, primary products have a low price elasticity of demand, so } \\
\text { a decline in their prices tends to reduce revenue rather than increase demand (leading to a secular reduction of the } \\
\text { terms of trade for primary exporting countries) }\end{array}$ \\
\hline sease & $\begin{array}{l}\text { The idea behind the Dutch disease is that the extra wealth generated by the sale of natural resources induces } \\
\text { appreciation of the real exchange rate and an ensuing contraction of investments in the traded sector, which ends up } \\
\text { losing international competitiveness }\end{array}$ \\
\hline $\begin{array}{l}\text { Loss in learnin } \\
\text { by doing }\end{array}$ & $\begin{array}{l}\text { The traded sector benefits the most from learning-by-doing and other positive externalities, while the commodity } \\
\text { export sectors do not entail as many opportunities for technological learning }\end{array}$ \\
\hline $\begin{array}{l}\text { Volatility of com- } \\
\text { modity prices }\end{array}$ & $\begin{array}{l}\text { Boom-bust cycles induced by volatile commodity prices lead to balance of payment crises and macroeconomic insta- } \\
\text { bility. }\end{array}$ \\
\hline $\begin{array}{l}\text { Government mis- } \\
\text { management }\end{array}$ & $\begin{array}{l}\text { Natural resource wealth may encourage countries to engage in "excessive" borrowing, reduction of productive and } \\
\text { infrastructural investments because the resources bonanza induces a false sense of economic security and lead to } \\
\text { postpone economic reforms }\end{array}$ \\
\hline $\begin{array}{l}\text { "Political" Dutch } \\
\text { disease }\end{array}$ & $\begin{array}{l}\text { Natural resource abundance induces political economy problems, such as rent seeking from political elites (who can } \\
\text { consolidate their power by allocating the surplus to their supporters) }\end{array}$ \\
\hline Corruption & $\begin{array}{l}\text { Resource dependence elicits corruption via exclusive licenses to exploit and export resources by the political elite, } \\
\text { oligarchs and their cronies to capture wealth and political power }\end{array}$ \\
\hline $\begin{array}{l}\text { Damages to insti- } \\
\text { tutional quality }\end{array}$ & $\begin{array}{l}\text { Natural resources can undermine democratic institutions and increase inequality. Badly defined property rights, } \\
\text { imperfect markets, and poorly functioning legal systems stifle entrepreneurial spirits }\end{array}$ \\
\hline $\begin{array}{l}\text { Conflicts over re- } \\
\text { sources control }\end{array}$ & $\begin{array}{l}\text { Higher resource income makes warfare more attractive as there is more to fight over and many rival groups try to } \\
\text { eize the rents generated by extractive activities }\end{array}$ \\
\hline
\end{tabular}

$$
\text { Sources: Auty (1983) Van der Ploeg (2011) and Venables (2016) }
$$

externalities, learning by doing and superior innovativeness (Dosi 1988; Szirmai 2012, Pisano and Shih 2012, Rodrik 2012; Stiglitz and Greenwald 2014). For all these reasons, the reduction of manufacturing activities can harm growth even in the years following the initial structural adjustment induced by trade dynamics, as it can be seen in the models of Matsuyama (1992) and Sachs and Warner (1995).

To conclude, a story based only on the optimality of comparative advantages as drivers of development is unable to explain both the historical record and the persisting international differences in income levels. Contrarily to what conventional wisdom takes for granted, large resource endowments often turn out to be a comparative dis-advantage in practice.

\subsection{Beyond Comparative Advantages: Competitiveness and International Trade}

An established tradition in economic research holds that technological change, despite having some informational features, is by and large an evolutionary process that advances along paradigms and trajectories (Dosi 1982 ; Dosi and Nelson 2010; Martinelli 2012). Unlike sheer information, knowledge is usually organization- and people-embodied, consisting of tacit elements (Bell and Pavitt, 1993) that make it spatially clustered and persistent. Given the complexity and cumulativeness of technology (Pavitt, 1987), learning and capability-building processes become of the utmost centrality for economic 
analysis. A first consequence of a theory of production based on such premises is the relevance of what can be labelled dominant (Dosi et al. 1990) or general purpose technologies (Bresnahan and Trajtenberg, 1995). These technologies often take the form of core inventions with the potential to enhance productivity or quality across a wide number of sectors because of technological interdependencies, hierarchical links between technologies and learning externalities. More interestingly for our analysis, general purpose technologies are double-edged swords that act both as enablers for new innovation and as constraints for those countries not mastering them. A country displaying a large gap in these core technologies will probably be severely impaired in its ability to profit from international trade irrespective of the pattern of comparative advantage, up to the point that it might not take part to it at all (Cimoli et al., 2009a).

Given the many sectoral peculiarities of technology (Pavitt 1984; Malerba 2002) ${ }^{5}$ one can specify sectoral trade performance as follows (Dosi et al., 1990):

$$
X_{i j}=f\left(T_{i j}, C_{i j}, O_{i j}\right)
$$

where $X_{i j}$ is a measure of how well a country $i$ does in sector $j$ relative to its trading partners. For instance, $X_{i j}$ can be taken to represent the market share of exports in a certain sector, and as such it is an indicator of how internationally competitive the country is in that sector. Following Dosi et al. (1990), we model competitiveness as a function of technological levels $T_{i j}$, variable costs $C_{i j}$ (mainly labour), and the sectoral forms of industrial organization $O_{i j}$. The latter variable takes into account the organizational specificities of each national industry and its path-dependent accumulation of organizational capabilities (Dosi et al., 2001). What Eq. 1 1 makes clear is that short-run variations in cost prices (such as currency devaluations or contraction of labor costs) can improve trade performance; however, these gains will prove ephemeral if they are not accompanied by technological upgrading in $T_{i j}$, especially for technological and skill-intensive sectors 6 Somewhat dramatizing, we are arguing here that in the majority of industrial sectors (especially high-wage innovative ones, e.g. aerospace) there is no way to challenge the industrial leaders (e.g. Airbus and Boeing) by means of cheap-labour

\footnotetext{
${ }^{5}$ While it is certainly true that each industrial sector shows specific traits, this approximation is not meant to neglect the considerable heterogeneity within sectors (Srholec and Verspagen, 2012) which can be very persistent over time (Coad, 2019).

"This is also implied by the so-called "Kaldor paradox", namely the fact that export market shares and relative unit costs/prices tend to move together over the long term for a number of countries (Fagerberg, 1996). The solution to this seemingly paradox has to be searched in technological upgrading raising both productivity and quality (Fagerberg, 1988), which allows to pay higher wages. This is a crucial hint that specialization patterns are fundamental determinants of the wealth of nations, given that some sectors and activities entail larger learning and innovation opportunities, in turn assuring higher wages and welfare (Cimoli et al., 2009a).
} 
only. Rather, the pattern of absolute advantage in the technological base will be the key determinant of international trade, as it has been confirmed by a large body of empirical literature at country (e.g. Fagerberg 1988) and sector level (e.g. Laursen and Meliciani 2002), which only recently has been complemented by firm-level analyses (Dosi et al. 2015).7

The discussion above also helps clarifying what we mean with the word competitiveness. A term first introduced and elaborated by scholars affiliated with the Berkeley Roundtable on the International Economy (BRIE), its most standard definition is the following 8

"[competitiveness is] our ability to produce goods and services that meet the test of international markets while our citizens enjoy a standard of living that is both rising and sustainable" (Tyson, 1993, p. 1)

Thus, competitiveness is mostly about engaging into "high-value" economic activities which are capable of granting national prosperity (Mulatu, 2016). The concept encompasses the familiar notion of productivity, but goes beyond it in recognizing that achieving efficiency per se is not a sufficient condition of prosperity (Reinert 1995, Reinert 2007; Cimoli et al. 2009a). Despite being extremely efficient and productive in the sector of their comparative advantages, many countries remain poor because they specialize in products which do not provide competitiveness in the "income-raising meaning of the word" (Reinert, 1995). In a sense, competitiveness is an "absolute" concept, because it is independent of intranational comparison of activities where a country is relatively better or worse, but rather compares one country with the rest of the world on the basis of sectoral absolute performance (Dosi et al., 1990).

Note that a Ricardian analysis based on comparative advantage can be derived from the framework presented above by taking ratios of sectoral competitiveness levels. The relationship between wage rates (in international currency) and average technological levels of each country determines the borderline between sectors of comparative advantage and those of comparative disadvantage (Dosi et al. 1990). In practice, comparative advantages are only an ex-post computation stemming from ratios

\footnotetext{
${ }^{7}$ For a systematic and updated review of empirical studies, see Dosi et al. (2015), Section 3.

${ }^{8}$ The notion of competitiveness remains a controversial one, and it historically spurred heated controversies (see the exchange on Foreign Affairs, Krugman 1994 and Cohen 1994). While neo-classical economists see it as "a poetic way of saying productivity" (Krugman, 1994), one can identify two main interpretations of the concept (Mulatu, 2016). The "quasi-competitiveness school" acknowledges that trade is tied to growth and in the absence of interventions it can have negative welfare consequences. However, this approach is mainly about benchmarking national economic performance relative to the other trading partners (Fagerberg 1996: Godin 2004). Rather, Dosi et al. (1990), Reinert (1995) and the BRIE group (Tyson 1993, Cohen 1994) espouse a more compelling definition taking into account that different economic activities entail varying levels of innovation and learning opportunities, which in turn translate in the well-being of citizens (low unemployment, high wages, and so on). Similar views are presented in Porter (1990), who adopts a perspective closer to business economic insights (see also Delgado et al. 2012 for more recent refinements).
} 
of absolute productivity levels, and many recent empirical applications do indeed recover measures of comparative advantages in this way (e.g. Hanson et al. 2015). Let us define a synthetic measure of competitiveness at country level:

$$
X_{i}=F\left(T_{i}, C_{i}, O_{i}\right)
$$

where the variables without the sector suffix are weighted averages across countries. Then, revealed comparative advantage as first defined by Balassa (1965) will be the ratio of two absolute measures of competitiveness:

$$
R C A_{i j}=\frac{X_{i j}}{X_{i}}=\frac{f\left(T_{i j}, C_{i j}, O_{i j}\right)}{F\left(T_{i}, C_{i}, O_{i}\right)}
$$

where $R C A_{i j}$ is the index of revealed comparative advantage of country $i$ in sector $j$ and the $X \mathrm{~s}$ are the already mentioned measure of absolute advantages, for instance the international market shares in sector $j 9$ Note that under the assumption of competitive conditions, the variable $O$ would become irrelevant; likewise, if international technological convergence were to be achieved, then $T$ would lose importance. As showed by Dosi et al. (1990), under these two conditions the determination of comparative advantage and of sectoral competitiveness become the same thing.

But what if these two conditions are not met? Then, the technological structure does not allow all relevant information about absolute levels to be summarized by comparing ratios. As a consequence, an analysis based only on comparative advantages can be highly misleading (MacDonald and Markusen, 1985), because countries with similar relative productivity can be very different in absolute technological levels 10 In turn, absolute technological levels (and not comparative ones) are a fundamental driver of trade performance and, ultimately, welfare. Technological capabilities constrain what a country is able to produce efficiently, with the ensuing consequences for its participation to world trade. To clarify the point, Cimoli et al. (2009a) describe the thought experiment of opening up trade between a "Stone Age economy" and an ICT-based one. As Ricardo would argue, the country coming from the Stone Age will be more likely to export "stone-intensive" products for which it has a comparative advantage (and viceversa for the ICT-based economy with, say, computers). However, there could be no bilateral trade at all if the more advanced ICT economy will end up producing almost anything worth trading irrespective of the stone- or ICT-intensities of the products. What

\footnotetext{
${ }^{9}$ Since Balassa's contribution, many refinement of his index have been proposed (e.g. Eaton and Kortum 2002). Still, the rather a-theoretical RCA index is very robust and remains a good approximation of the data (French 2017). Dosi et al. (1990) note that RCA are basically "revealed relative allocations" stemming from intra-country differences in technological and productivity levels between sectors.

${ }^{10}$ To say it with a vivid example of MacDonald and Markusen (1985 p. 278) : "It is not persuasive that the employee with the highest comparative advantage in management should become president. Indeed it is plausible that the presidency assignment will have something to do with absolute advantage; alternatively, a person with poor management skills will not be chosen even if he is relatively worse at every other task in the firm".
} 
really matters for economic growth might ultimately be absolute levels of technological capabilities and how they interact with world demand for products, as we shall discuss in what follows.

\subsection{The Effects of Trade upon the Process of Development}

Following Dosi et al. (1990), we outlined above two research traditions in international trade. On the one hand, conventional theories of trade locate the source of trade in differing resource endowments and they rely on comparative advantage as the key determinant of trade flows. On the other hand, a second "heretic" line of thinking locates the main source of absolute technological advantages into the accumulation of technological capabilities. The latter provides a consistent explanation of the persistent cross-country heterogeneity in output growth (Castaldi et al., 2009) and technological levels (Fagerberg, 1994), with the accumulation of technological capabilities accounting for the markedly different paths of specialization and trade observed (Bell and Pavitt, 1993). In this perspective, comparative advantages are reduced to the ex-post outcome of technological learning processes, and public policies are of the utmost importance for the acquisition of absolute technological advantages and competences $($ Dosi et al. 1990 ; Bell and Pavitt 1993; Cimoli et al. 2009a; Mulatu 2016; Juhász 2018).

The two lines of thought also differ in their predictions about the dynamics of trade-induced structural change. Mainstream trade theories generally hold that free trade benefits every country taking part to it, even those showing an absolute disadvantage in every sector. In general equilibrium models, specialization according to comparative advantages is usually shown to be the best strategy for structural transformation, because it leads to a globally optimal utilization of resources. The fundamental premise is what we can call a Ricardian adjustment mechanism (Dosi et al. 1990). To put it bluntly, Ricardian adjustments are stationary adjustment processes (i.e. holding technology constant) based on the behavioural tendency at the microeconomic level towards minimum-cost/maximum-profit activities. The standard assumption in these models is that adjustment processes do not affect the rate of utilization of the stock of inputs themselves, so that trade affects the intersectoral allocation of inputs quantities and prices only. Even under this heroic assumption, conforming to comparative advantage induces at best a once-and-for-all increase in the short-term efficiency of the international location of productive activities.

Suppose now that, due to a successful innovation, any one country $i$ improves its productivity in sector $j$, i.e. it increases its absolute advantage in only that sector. Clearly, an increase in productivity (and hence profitability) of that sector would spur the comparative advantage mechanism of adjust- 
ment and change the intersectoral allocation of resources, thus leading to structural change exactly in the direction indicated by comparative advantages. However, increased technological capabilities in a certain sector vis-á-vis foreign competitors will also lead to an increase in world-market shares of country $i$ in that sector (Dosi et al. 1990). This additional competitiveness-related mechanism of adjustment entails macroeconomic dimensions, such as changes in the absolute amount of employed resources, rate of growth and wage rates. Higher export market shares will lead to higher levels of economic activity, with the gains of increased competitiveness distributed between higher growth and higher wages. If higher world-market shares in sector $j$ for country $i$ were matched with unchanged world-market shares in all the other sectors, then it can be concluded that a gain in competitiveness will unambiguously be a Pareto improvement. More likely, the increase in wages could harm competitiveness in other sectors, but still without eroding all the other gains of the innovative process (Dosi et al., 1990).

Besides sheer Ricardian static efficiency, we can introduce two other efficiency criteria to evaluate trade-induced structural change. Keynesian efficiency relates to the property by which open economies pull each other's demand via imports, while at the same time constraining each other's possibilities of growth via the need to balance the foreign accounts (Cimoli 1988; Dosi et al. 1990). International trade flows entail an often neglected macroeconomic dimension insofar producing goods with high foreign demand stimulates domestic economic activity. Instead, Schumpeterian efficiency is a dynamic concept that pertains technological change and the specialization in sectors that create more technological externalities, have higher technological opportunities and exhibit higher rates of innovation. The paramount importance of technical change in shaping the possibilities of economic growth clarifies why Schumpeterian adjustments are fundamental: specialization in the most innovative sectors dominates over the short-term gains induced by Ricardian comparative advantages ${ }^{11}$

To make a similar point, Erik Reinert proposes two ideal types of economic activities, which he dubs Schumpeterian and Malthusian. While the former are distinguished by continual innovations and dynamic increasing returns that lead to increasing wages and prosperity, the latter keep low wagelevels because of the absence of technological learning. Not surprisingly, Schumpeterian activities are more common in manufacturing, whereas the other category is found typically in agriculture and commodity production (Reinert 2007; Hausmann et al. 2007). Resource-based economic activities also

\footnotetext{
${ }^{11}$ Analogue conclusions and policy suggestions are derived with a formal apparatus by the New trade theory, by simply allowing for some form of increasing returns and imperfect competition. Even without adopting an evolutionary view on technology, the sheer presence of dynamic scale economies in the form of learning-by-doing are sufficient to justify policy interventions to alter the given pattern of comparative advantages (Krugman, 1987).
} 
suffer from an additional drawback, namely diminishing returns (Reinert, 1996). Output increases in resource-based activities will eventually lead to reach a point after which the crucial resource is no longer available or it is left only in lower quality (extractive activities provide a straightforward example of such a situation). This is what Reinert (1996) dubbed "double trap of resource-based nations": the resource-based nation is locked into an economic activity which yields less and less as its specialization according to its comparative advantage deepens.

In synthesis, (technological) absolute advantages can be said to dominate over comparative advantages as determinants of trade flows: absolute advantages account for most of the composition of trade flows by country and by commodity and explain the evolution of such trade flows over time. In general, the most advanced countries will show a higher participation in world trade in their sectors of comparative disadvantage than will any backward country show in its sector of comparative advantage, due to the absolute macroeconomic dimension that competitiveness entail (Dosi et al., 1990). However important, the efficacy of Ricardian adjustment mechanisms are constrained by absolute levels of competitiveness and the ensuing world market shares. Only in a world tending to technological convergence, intra-country mechanisms of specialization related to comparative advantages are the fundamental factor in explaining patterns of trade-induced structural change. The opposite will apply to a world where technological asymmetries are increasing (or at least not reducing): sectoral technological absolute advantages between countries ultimately become the major determinant of international market shares. This situation justifies the need for policies that direct structural transformation against comparative advantages in order to specialize in activities characterized by increasing returns, learning and positive externalities (Krugman 1987; Reinert 2007; Chang 2002, Cimoli et al. 2009a; Stiglitz and Greenwald 2014).

\section{Why Competitiveness Matters: Insights from a stylized Technol- ogy Gap model}

The previous section discussed the main theoretical underpinnings of a theory of absolute technological advantages, discussing how it differs from trade theories that rely on endowment-based comparative advantages. In order to explore the consequences of trade on structural change, we will now rely on the Dosi-Pavitt-Soete (DPS) model (Dosi et al., 1990) which we will present in a simplified version (for a full-fledged technological gaps model in the tradition of Latin American Structuralism, see the Chapter by Porcile). The model will also be useful later, when we will discuss the consequences 
of the recent globalization patterns.

Let us assume the existence of two kinds of commodities. The first group is constituted by $R i$ cardian commodities, i.e. goods that are traded only on the grounds of their cost of production. The second group are the innovative commodities, whose production requires the possession of adequate technological capabilities. We next assume that the only production input for both groups of products is labour. For the sake of simplicity, we will further postulate the existence of only two countries, $A$ and $B$, with the former being the only one capable of producing and exporting innovative commodities 12 The labour input coefficients for the production of Ricardian commodities will be $a_{1}, a_{2}, \ldots$, $a_{n}$ and $a_{1}^{*}, a_{2}^{*}, \ldots, a_{n}^{*}$ for country $A$ and $B$ respectively. If these coefficients are ranked according to the diminishing comparative advantage of country $A$, we will have:

$$
\frac{a_{1}^{*}}{a_{1}}>\cdots>\frac{a_{i}^{*}}{a_{i}} \geq 1>\cdots>\frac{a_{n}^{*}}{a_{n}}
$$

where, for instance, country $A$ has the largest comparative advantage on the first few Ricardian commodities, a situation that reverses after commodity $i$. Calling $z$ the generic Ricardian commodity, for each $z$ we can define the following function $A(\cdot):[0,1] \mapsto \mathbb{R}_{+}$:

$$
A(z)=\frac{a^{*}(z)}{a(z)} \quad \text { with } \quad A^{\prime}(z)<0
$$

International specialization for each commodity in $A$ or $B$ will depend on the relative unit labor cost, in turn depending on the labour input coefficients and the wage rates $w$ and $w^{*}$ :

$$
a(z) \cdot w \gtrless a^{*}(z) \cdot w^{*} \text { i.e. } \omega \gtrless A(z) \text {, with } \omega \equiv \frac{w}{w^{*}}
$$

Figure 1 summarizes the model thus far. At the generic wage ratio $\omega$, country $A$ specializes in the set of commodities from $r_{0}$ to $z_{0}$, where $z_{0}=A^{-1}(\omega)$ is the borderline commodity separating the group of products for which $A$ has a comparative advantage. The graph also shows the effects of an increase in productivity in $A$ (for instance as a consequence of process innovation) that moves the $R_{0}$ line to $R_{1}$, thus allowing for a wider specialization (arrow (1) in Fig. 1) for a given wage ration $\omega_{0}$, or a higher wage ratio for a given specialization (arrow (2)).

However, this applies only for Ricardian commodities: the set of innovative commodities (from the origin to $r_{0}$ ) will be produced and traded only by the technological leader, which we assumed to

\footnotetext{
${ }^{12}$ The two countries correspond to what could be labelled North and South in the terminology introduced by Ronald Findlay in his models.
} 
be country $A$. Therefore, an increase of the domestic wage relative to the commercial partner will reduce the set of commodities which the country can competitively produce, but does not affect the international distribution of technological capabilities (and hence the production of innovative goods). Rather, country $B$ enact industrial and trade policies capable of reducing its technological gap, that is shifting $r_{0}$ towards the origin as showed by the arrow labelled (3). The model helpfully highlights the limits of Ricardian adjustment processes for developing countries, that is structural change in the pattern of production on the basis of comparative advantage. In terms of Figure 1), $r_{0}$ is the borderline commodity between innovative and Ricardian products and any increase in the wage ratio $\omega$ above $\omega_{r_{0}}$ (due for example by a decrease in $B$ 's wages) will have no effect on specialization; if anything, it would only worsens the terms of trade for $B$.

This sketch of the DPS model highlights the possibility of unintended consequences of trade liberalization, that is what can be dubbed "Vanek-Reinert effect" (Reinert, 2007): a sudden overture of trade between nations with asymmetrical technological levels will likely harm the most advanced and knowledge-intensive industry of the more backward country. A corollary of such mechanism is the impact on growth of the least advanced countries, given that the most advanced sectors are the ones most subject to dynamic increasing returns. Reinert (2007) goes on arguing that the ensuing

$(2)$

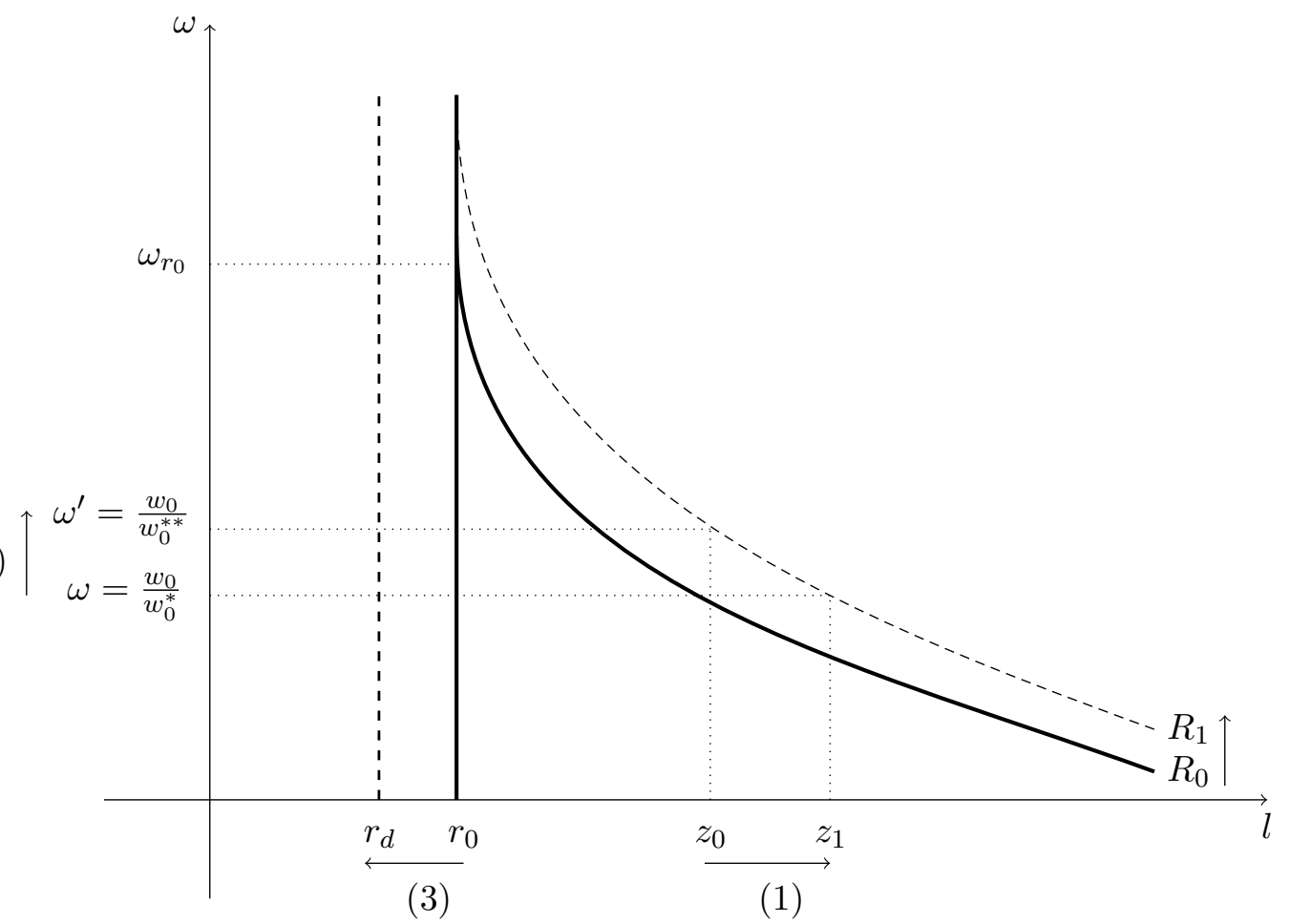

Figure 1: International specialization with a continuum of Ricardian and innovative commodities 
"primitivization" the national production system will ultimately reduce welfare as it will eliminate the production of innovative goods in developing countries (resulting in $r_{0}$ shifting to the right in Figure 1) 13 Premature liberalization can have negative consequences protracted over time. Due to the presence of localized increasing returns and technological learning, greater trade integration might lead to phenomena of economic divergence with lock-in of particular production activities and specialization patterns (Dosi et al. 1990; Cimoli et al. 2009a). This point is explored in detail by the tradition of Latin American Structuralism (see the Chapter by Porcile), which explicitly deals with the center-periphery dynamics that emerge between unequal trading partners (as eloquently shown in the North-South model developed by Cimoli 1988).

To map these processes of production and specialization to income and employment, we follow Dosi et al. (1990) and assume that national incomes of $A$ and $B$ will be given respectively by:

$$
Y=w N \text { and } Y^{*}=w^{*} N^{*}
$$

where $w, w^{*}$ and $N, N^{*}$ are wages and employment levels in country $A$ and $B$ respectively. This formulation is a reasonable approximation given our assumption of labour as the only production input. Note that the employment levels $N$ are not necessarily equal to the whole labour force $L$, that is $N \leq L$ and $N^{*} \leq L^{*}$. Finally, in our simplified model with only two countries, it must be that each economy satisfies the trade-balance constraint. The GDP of each country will be given by the sum of internal demand and exports (i.e., external demand), which in turn represent the other country's imports. ${ }^{14}$

Figure 2 illustrates the whole picture constituted by the system of equations 6,7 and 8 , The line $S$ in the top-left quadrant is the locus of the ratios between wages in $A$ and $B$ that guarantee a certain specialization, as represented by commodity $z_{0}$ in Figure 1. Each pattern of international specialization corresponds to a line $T B$, representing the locus of equilibrium points for the trade balance between the two countries. In the simplest case of $Y=w N$, the angle $\alpha$ is a measure of employment in country $A$, and the same applies for $\alpha^{*}$ and country $B$. The situation represented

\footnotetext{
${ }^{13}$ The same mechanism is dubbed by Dani Rodrik as "imported deindustrialization": a sudden opening of developing countries to free trade can reverse long processes of import-substitution and lead to a decline in manufacturing capabilities.

${ }^{14}$ More formally, we have that the income of country $B$ multiplied by its import propensity must equal that of country $A$ times the latter's import propensity, a simple accounting equality (Dosi et al., 1990). If we specify import propensity as a function $\phi(\cdot)$ of the commodity $z$ in question and of both national and international wage rates (the first affecting consumption and the latter imports' costs), we can write (Dosi et al., 1990):
}

$$
\frac{Y}{Y^{*}}=\frac{\phi^{*}(z, \omega)}{\phi(z, \omega)}
$$




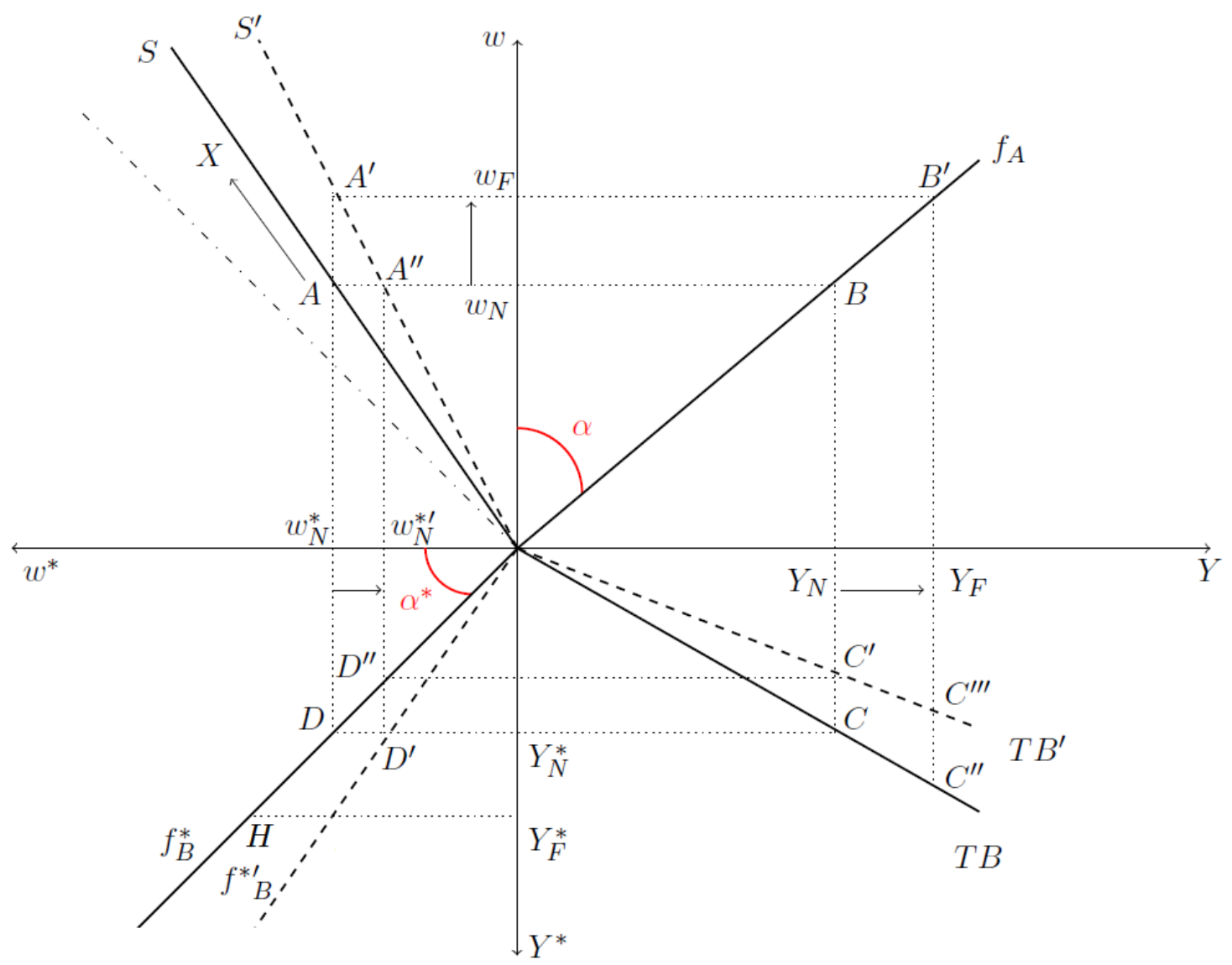

Figure 2: An illustration of the relationship between specialization, trade and levels of macroeconomic activity

shows country $A$ having an absolute advantage in productivity over its trading partner, thus the line $S$ lies above the dash-dotted 45-degree line.

Let us start from an initial situation corresponding to the points $A B C D$ on the thick lines $S$, $f_{A}, T B$ and $f_{B}^{*}$ respectively. Country $A$ has higher technological capabilities and this allows higher absolute productivity and higher wages. Still, neither country is at full employment levels: for instance, given the current international specialization and wage rate $w^{*}$, country $B$ would reach full employment in point $H$, which is however incompatible with the current trade balance $T B$. Nevertheless, the situation represented here is efficient in static allocative terms, because it satisfies by construction the Ricardian criterion of efficiency discussed in Figure 1. Another point worth noting is the dominance of absolute technological levels in the determination of income. Ceteris paribus, an increase in absolute productivities shifting point $A$ to point $X$ would leave both countries better off, irrespective of comparative advantages. This mirrors the point of MacDonald and Markusen (1985) that relative measures can obscure the importance of absolute levels, often more relevant in economic terms. 
Suppose now that the line $S$ rotates to $S^{\prime}$ because there is a change in the international wage ratio $\omega=\frac{w}{w^{*}}$. This could happen because country $B$ reduces its wages from $w_{N}^{*}$ to $w^{* \prime}$, so that point $A$ moves to $A^{\prime \prime}$ if wages (and hence income) in the technological leader $A$ do not change. The new situation could turn out to be favourable to the developing country $B$ because point $D$ moved to $D^{\prime}$, corresponding to a higher employment. But what if the reduction of wages changed the comparative advantage of $B$, thus leading it to specialize in commodities that a lower share of consumers in country $A$ is willing to buy? In this case, a reduction in imports from $A$ shifts the trade balance constraint to $T B^{\prime}$, completely off-setting the employment gains resulting from the wage-cut $\left(f_{B}^{* \prime}\right.$ rotates back to $f_{B}^{*}$ and $D$ goes to $\left.D^{\prime \prime}\right)$. Country $B$ is now poorer because its Ricardian adjustment process led to the "wrong" kind of specialization. Similarly, an increase in the technological gap could move point $A$ to $A^{\prime}$. If $T B$ and hence the import-propensity of $A$ stay unchanged, then country $B$ would experience an increase in income and employment (because $C$ moves to $C^{\prime \prime}$ and requires $f_{B}^{*}$ to rotate to the right). This apparently paradoxical result is due to the increase of GDP and consumption in the richest country $A$, which could translate in higher imports from country $B$. But again, if technological advance makes country $A$ capable of efficiently producing almost all worth trading, then $T B$ would rotate upward to $T B^{\prime}$ and wipe out the possible gains for the laggard country. This once again clarifies the relevance of Keynesian efficiency relative to microeconomic criteria of efficiency in the spirit of Ricardo.

Specialization patterns thus bear important implications for international competitiveness: engaging into high-value sectors (usually the high-technology ones) characterized by a high income elasticity of demand and high learning opportunities will likely result in higher wages and wealth for the entire country (Cimoli et al., 2009a). This remark, which may at a first glance appear a platitude, for a too long time has been a controversial view in the economic debate. Indeed, a strict application of neoclassical trade theory would imply the infamous proposition attributed to Michael Boskin, who allegedly claimed that "it does not make any difference whether a country makes potato chips or computer chips!" (Thurow, 1994). In this perspective, specialization along comparative advantages would always be the best path to prosperity, whatever the outcome of the specialization process. Ricardian trade theories are rather agnostic on the quality of goods traded, implicitly assuming that trade is good for everyone no matter the kind of goods effectively traded (Kemp and Van Long, 1984). Both common sense and economic research show that this is not the case (Reinert 2007; Hausmann et al. 2007), and specialization patterns are highly predictive of economic performances (Tacchella et al. 
Table 2: Productivity of labour for selected countries and sectors in 2005.

\begin{tabular}{|c|c|c|c|c|c|}
\hline & \multirow{2}{*}{$\begin{array}{c}\text { Labor productivity } \\
\text { economy-wide }\end{array}$} & \multicolumn{2}{|c|}{ Sector with highest labour productivity } & \multicolumn{2}{|c|}{ Sector with lowest labour productivity } \\
\hline & & sector & productivity & sector & productivity \\
\hline USA & 70,235 & public utilities & 391,875 & construction & 39,081 \\
\hline France & 56,563 & public utilities & 190,785 & personal and public services & 37,148 \\
\hline Argentina & 30,340 & mining & 239,645 & finance, business services & 18,290 \\
\hline Nigeria & 4,926 & mining & 866,646 & personal and public services & 264 \\
\hline
\end{tabular}

Source: McMillan and Rodrik (2011). Figures are in 2000PPP\$.

2012), 15

However, comparative advantages might not induce a country to specialize in those sector: if left to themselves, countries endowed with natural resources will likely end up exporting primary goods. Consider for instance the labour productivity level reported in Table 2, taken from McMillan and Rodrik (2011). Inter-sectoral productivity levels tend to be much wider in developing countries, with the staggering example of Nigeria making the point. If anything, this should spur Ricardian processes of resources reallocation toward more efficient and remunerative sectors, in turn providing growth-enhancing structural change. However, the issue here is the nature of sectors where developing countries often show high productivity, namely commodities production. The problem for countries with large endowments in natural products is that primary sectors operate at relatively high productivity levels, but they generate very low employment (McMillan and Rodrik, 2011). Inter-sectoral comparative advantages are thus misleading drivers of development, and the positive impact of structural change is found to be larger for countries that manage to reallocate a large share of employment to manufacturing activities (McMillan et al., 2014). To paraphrase Amsden (1989), countries rich of natural endowments should "get Ricardo wrong" and use industrial and trade policies to alter the given pattern of comparative advantages.

In conclusion, the key point for policymakers is that sheer acceptance of comparative advantages might not be sufficient to achieve satisfactory competitiveness levels. Not every type of manufacturing activity is bound to generate the same levels of learning and accumulation of technological capabilities. Different commodities and sectors are likely to be associated with different levels of opportunities for innovation and different income elasticities of demand (Dosi et al., 1990). The presence of increasing returns and learning effects might even "lock-in" the economy into an inferior technology (David 1985; Dosi et al. 1994). It is thus easy to imagine situations where Ricardian efficiency in static terms could conflict with the achievement of the maximum rate of innovative dynamism, namely Schumpeterian

\footnotetext{
${ }^{15}$ See also the Chapter by Freire for a review of the product-space literature that makes a similar point.
} 
efficiency. Similarly, countries might "efficiently" specialize in the production of commodities that a small or decreasing number of world consumers wants to buy, with the ensuing negative long-term effects in terms of Keynesian efficiency (Dosi et al., 1990) ${ }^{16}$

\section{Structural Change on the basis of Comparative Advantages: a Discussion of the Empirical Evidence}

\subsection{Many Exceptions or a Different Rule? The Historical Evidence}

Since the late 1950s, the economics profession has been investigating the issues of growth and

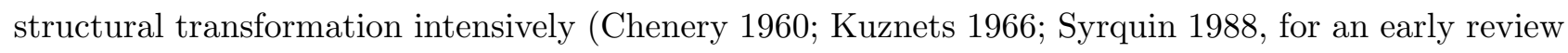
of the literature). In his Nobel Prize lecture, Kuznets (1973) highlighted what he saw constituting the main characteristics of modern economic growth. Indeed, the third of these "Kuznets facts" is the high structural transformation rate of the economy: Kuznets was referring to the progressive shift away from the industries relying on natural resource endowments (agriculture, mining, commodities) toward manufacturing and services (Herrendorf et al. 2014$)$. In general terms, a stylized fact is that successful development entails a systematic effort to build a national production capacity Cimoli and Dosi, 1995), a process that does not need particular starting endowments to be successful.

A comprehensive historical overview of successful cases of structural transformations and industrialization is provided by Ha-Joon Chang (2002). The most telling cases of successful latecomers' industrialization are probably the United States and Germany. Indeed, it was the first Secretary of the US Treasury, Alexander Hamilton, who systematically elaborated the infant industry argument in 1791. In a nutshell, Hamilton argued that foreign competition would have prevented domestic industries from becoming internationally competitive, unless the state had intervened to compensate initial losses or to enforce import duties (Hamilton, 1791). American industries ended up being literally the most protected in the world until after WWII (Chang, 2002): needless to say, this goes a long way in explaining the US pattern of structural change. Furthermore, the role of the Federal government in industrial development has been substantial even in the post-war era, thanks to the large amount of defense-related procurement and mission-oriented research (Mazzucato 2013; Mowery 2012) 17 Similarly, in List (1841) we find a very lucid discussion of the shortcomings of simply

\footnotetext{
${ }^{16}$ This is precisely what Engel's law would predict for the primary sector: as per capita incomes rise, the share of agricultural expenditures in total expenditures declines due to low income elasticity (Szirmai and Verspagen, 2015).

${ }^{17}$ The United States also benefited from abundant natural resources, but their role in explaining the American longstanding success is controversial. Wright (1997) and David and Wright (1997) suggest that the contribution to growth of the fixed set of natural endowments was the outcome of technological learning coupled with institutional arrangements
} 
adhering to comparative advantages: in his view, the true objective of developed countries trying to impose free trade over Europe was simply "kicking away the ladder" that they themselves had climbed (Chang, 2002). The German experience also points to the importance of ad-hoc institutional innovations which facilitated catching-up and were the basis of the successive forging ahead with respect to Britain. Of particular importance was the introduction of the Humboldtian university for the education of graduate engineers, which supplied human capital that proved essential for the diffusion of in-house industrial R\&D departments (Dosi et al., 1994). Another pillar of German industrialization was the emulation of imported British machine tools (often thanks to British craftsmen attracted to Prussia, Freeman 1995). More recently, Japan (Freeman, 1987) and the Asian tigers (Nelson and Pack, 1999) were able to reap the benefits from fast growing technological markets. At the roots of the Japanese success there was the explicit decision by Japanese political authorities to neglect the path of "natural" development implied by comparative advantages (Freeman, 2004). In few years, Japan ceased being an importer of foreign technology and developed important indigenous innovation capabilities, even surpassing the United States in terms of R\&D efforts. The secret of its success was building up of one of the most successful Innovation Systems (which inspired the formulation of the concept itself, see Freeman 1987), where the long-term planning of the MITI fostered learning and spurred innovation in the export-led industrial complexes.

The classic works mentioned above are detailed case-studies of single countries and their historical experience. More recently, research leveraging natural quasi-experiments and new estimation techniques has allowed the precise causal identification of the effects of sectoral policies. For instance, China's $11^{\text {th }}$ five-year plan (2006-2010) promoted shipbuilding as a strategic industry for defenserelated purposes. Kalouptsidi (2017) finds that the reduction in production costs associated with the policy explains the massive Chinese gains of global market shares in ships: in the absence of the targeted subsidies, China's production would be cut to less than half. Lane (2017) studies the Heavy Chemical and Industry (HCI) policy that South Korea enacted in 1973 as a response to the US troop withdrawal. Again, targeted industries were chosen for their military importance, and the comparison with otherwise similar industries shows that the policy promoted rapid development that lasted long after the measures were removed. Interestingly enough, downstream sectors also benefited from the lower prices induced by the policy, an instance of the policy-induced industrial externalities that that encouraged both public and private search efforts. However, other historical accounts question the belief that natural resource endowments actually fostered US industrialization. Allen (2014) argues that abundant natural resources eventually retarded the industrialization of the United States given that the large volumes of exports of primary products were inflationary and produced a Dutch disease situation. 
Hirschman (1958) labelled "forward linkages". The HCI entailed both industrial subsidies and targeted trade protection; nonetheless, it must be noted that in certain situations sheer trade protection can be sufficient to change the patterns of trade and allow industrialization. Juhász (2018) documents that the temporary protection from British imports caused by the Napoleonic Blockade was fundamental in the accumulation of technological capabilities in $19^{\text {th }}$ century France. The mechanized cotton-spinning industry rapidly developed in French departments that received more sheltering, in plain accordance with the predictions of the infant industry argument. Hanlon $(2019)$ complements this evidence by looking at production input advantages, instead of output market protection. Using data from last century's metal shipbuilding, he shows that even a temporary cost advantage can become the source of long lasting competitive advantage due to dynamic localized learning effects and learning-by-doing.

Some general patterns can be distilled from these historical cases. First, all countries that successfully industrialized appear to have been guided by the principle of emulation of the countries at the technological frontier (Reinert, 2007). Countries that have got rich have usually disregarded their endowment structures, rather preferring to "get the prices wrong" and guide their structural transformation toward high value added sectors (Amsden, 1989). Secondly, as the Japanese and German experiences highlight, successful development can rarely be achieved without introducing the necessary social technologies and institutional changes tailored on the specific needs of the country (Abramovitz 1986; Dosi et al. 1994; Nelson and Sampat 2001).

As a final point, virtually every now developed country actively used industrial and trade policies, often combining them in order to nurture the necessary technological capabilities. Each country had to develop its own substitutive factors according to its idiosyncratic necessities and the then prevailing techno-economic paradigm (Gerschenkron 1962; Dosi et al. 1994; Reinert 1999; Freeman and Louçã 2001). Often, the state had to do more than simply forcing entrepreneurs into certain strategic sectors, sometimes even ending up acting as "entrepreneur of last resort" (Reinert 1999; Baldwin and Krugman 1988; Head 1994$) 18$

\subsection{Comparative Advantages after Globalization}

Starting from the early 1980s, a set of policies emerged to form a rather invariant recipe for development routinely proposed to developing countries. These policies, known under the heading of

\footnotetext{
${ }^{18}$ These considerations notwithstanding, one has to bear in mind also the many instances where industrial policies failed in achieving their aims (Harrison and Rodríguez-Clare, 2010). The interested reader is referred to the discussion in Cimoli et al. (2009a) on the practical challenges in designing industrial policies consistent with the internal power balances and institutional setting of each country.
} 
"Washington Consensus", rested over three main tenets: a market economy, openness to the world, and macroeconomic discipline (Rodrik 2006, Serra and Stiglitz 2008). The Consensus entailed a development strategy markedly differed from the set of policies followed by development states during the previous decades (and centuries). In practical terms, it translated into deep fiscal adjustment and a dramatic reduction for the role of the state in the economy. The Consensus also spurred a widespread liberalization of international trade and generalized reduction of tariffs. The new trade landscape, crystallized by the creation of the World Trade Organization in 1995, entailed very low tariffs on industrial products, with very narrow tariff dispersion both across countries and across products (Akyuz, 2009). The policy space of single countries was substantially reduced, depriving them of basically every industrial and trade policy tools.

The DPS model (Dosi et al., 1990) presented in Section 3 can help shed some light on the consequences of globalization on the dynamics of trade-induced structural change. First, we already mentioned the Vanek-Reinert effect (Reinert, 2007) or imported deindustrialization (Rodrik, 2016). Technological gaps strongly condition the dynamics of trade, and Ricardian adjustment processes tend to go against the accumulation of technological competences over time, thus leading to a polarization of manufacturing capabilities in few countries. Premature liberalization can also have negative consequences protracted over time. Given the presence of localized increasing returns and learning, greater integration may lead to phenomena of self-reinforcing lock-in in production activities which are not efficient in Schumpeterian and Keynesian terms (Dosi et al. 1990; Cimoli et al.2009a). Finally, the curtailing of policy space might increase the relative importance of natural resources endowments and curb the virtuous structural transformation of less developed countries into industrial economies (McMillan and Rodrik, 2011). Said otherwise, unbridled globalization might increase the influence exerted by comparative advantages on structural change.

McMillan and Rodrik have investigated the role of natural resources in structural change in a series of recent studies (McMillan and Rodrik 2011; McMillan et al. 2014, Diao et al. 2017). Their basic finding confirms our expectations: when globalization is not moderated by policies to guide structural transformation, countries specialize according to comparative advantages. Still, this specialization faces physiological limits due to the very low employment that the primary sector can generate, despite operating at relatively high productivity levels.

Figure 3 from Fally and Sayre (2018) seems to document a secular decrease in the share of primary commodities in world trade. Besides structural change and the growth of trade in manufacturing, one explanation of this decline is due to the declining real price of commodities (Figure 4, see also 


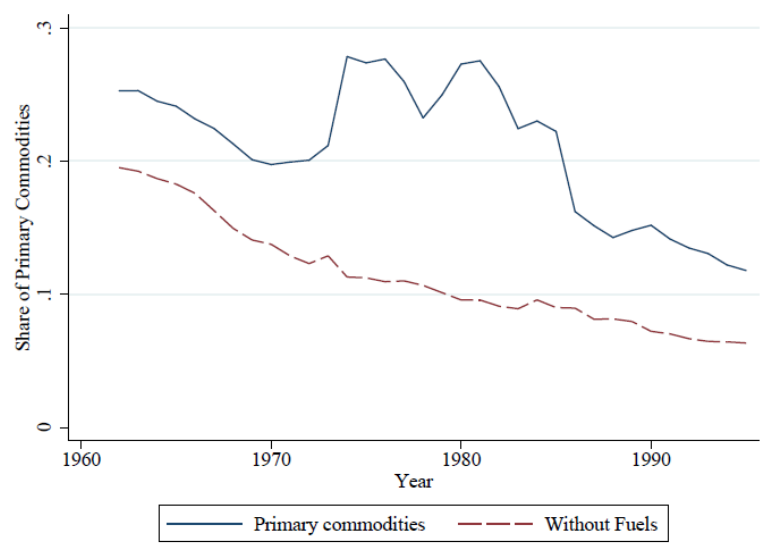

(a) $1962-1995$ (Feenstra data)

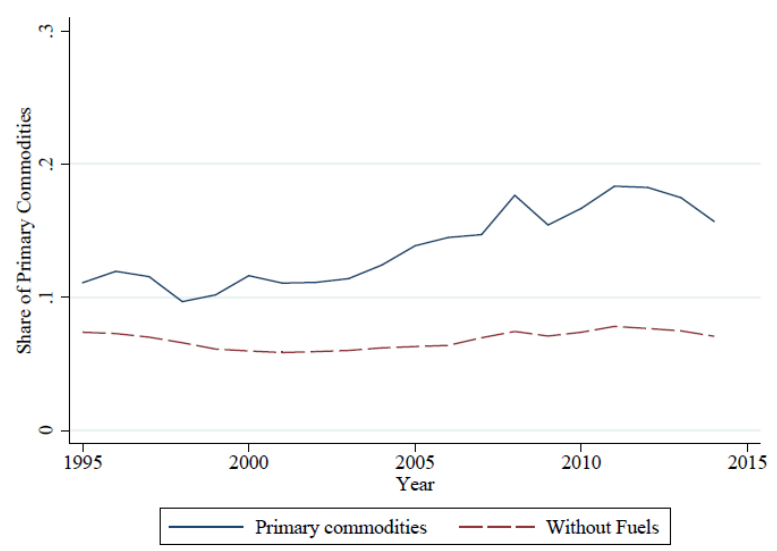

(b) 1995-2014 (BACI data)

Figure 3: Evolution of the share (in value) of primary commodities in world trade Source: Fally and Sayre (2018), Fig. 2 page 8

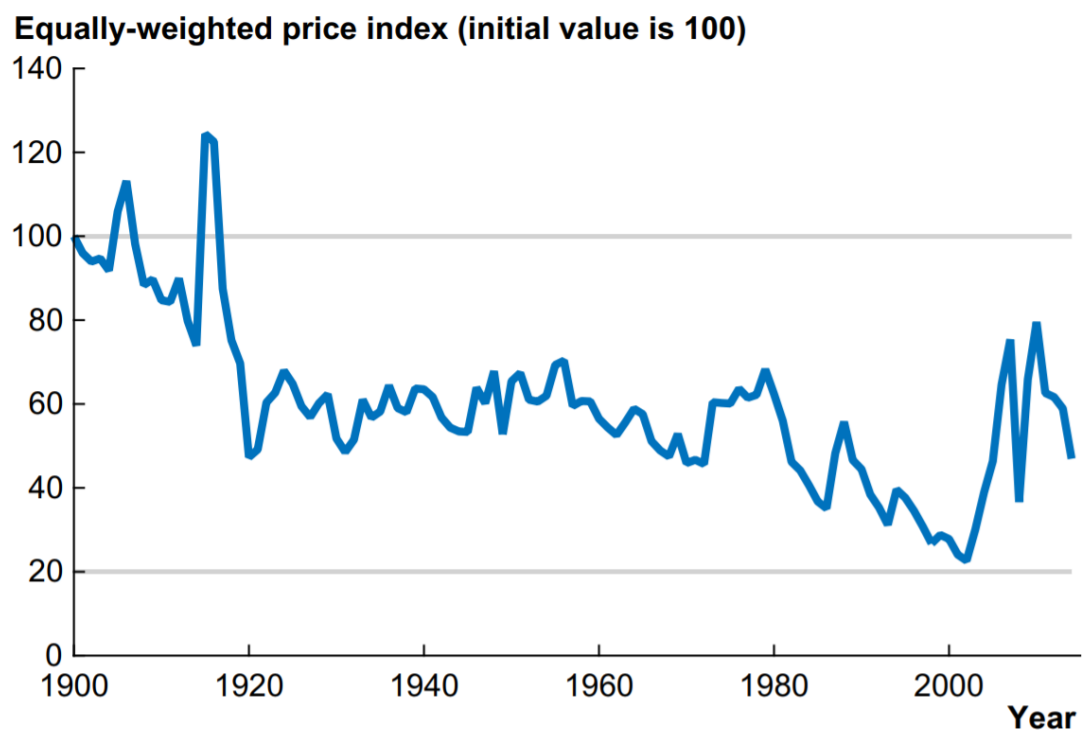

Figure 4: The real price of industrial commodities (aluminum, coal, copper, lead, iron ore, and zinc) Source: Jones 2016), Fig. 20 page 31

the discussion in Jones 2016). Still, the low demand and supply elasticities of commodities make fluctuations in their prices very pronounced (Fally and Sayre, 2018) and usually much higher than price changes in manufactured goods (Jacks et al., 2011). Given that for many developing countries primary products constitute the majority of their exports (Fally and Sayre, 2018), the consequences of this volatility can be very large and partially account for the slow growth of resource-dependent countries (James, 2015).

However, what Figure 3 also shows is a pick-up of trade in commodities starting from around the year 2000, as well as a large increase in their real price (Jones, 2016). Part of the explanation is to 
be found in the rapid growth of China and India over this period, which entailed a large increase in the demand for commodities. Be that as it may, this phenomenon had two effects on development countries: while initially stimulating growth, they also led to an increasing reliance on exports of natural resources, thus reinforcing structural change along comparative advantage. Suggestive descriptive evidence is provided in Figure 5, which summarizes the growth of export production during the past decade broken down by sector. While developed countries mostly exported services and manufacturing goods, Latin America, Middle East and North Africa (MENA) and sub-Saharan Africa (SSA) witnessed increases of exports concentrated in natural commodities (amounting to 30\%, $42 \%$ and $31 \%$ respectively, see Verspagen and Kaltenberg 2015).

As predicted by the DPS model, this situation has the double effect of pushing toward specialization in commodities through Ricardian adjustments while impeding the formation of an industrial sector capable of absorbing a larger fraction of the workforce. The empirical evidence by Coniglio et al. (2018) confirms how large natural resource endowments make it more difficult to diversify away from the current comparative advantage. For every dollar of resource exports it is estimated that 74 cents of non-resource exports are displaced (Harding and Venables, 2016). In the absence of proper policies, a restricted number of developed countries has remained the technological leader (Castaldi et al. 2009, Castellacci 2008), with very few new entries in this "technology club" (Castellacci and Archibugi, 2008).

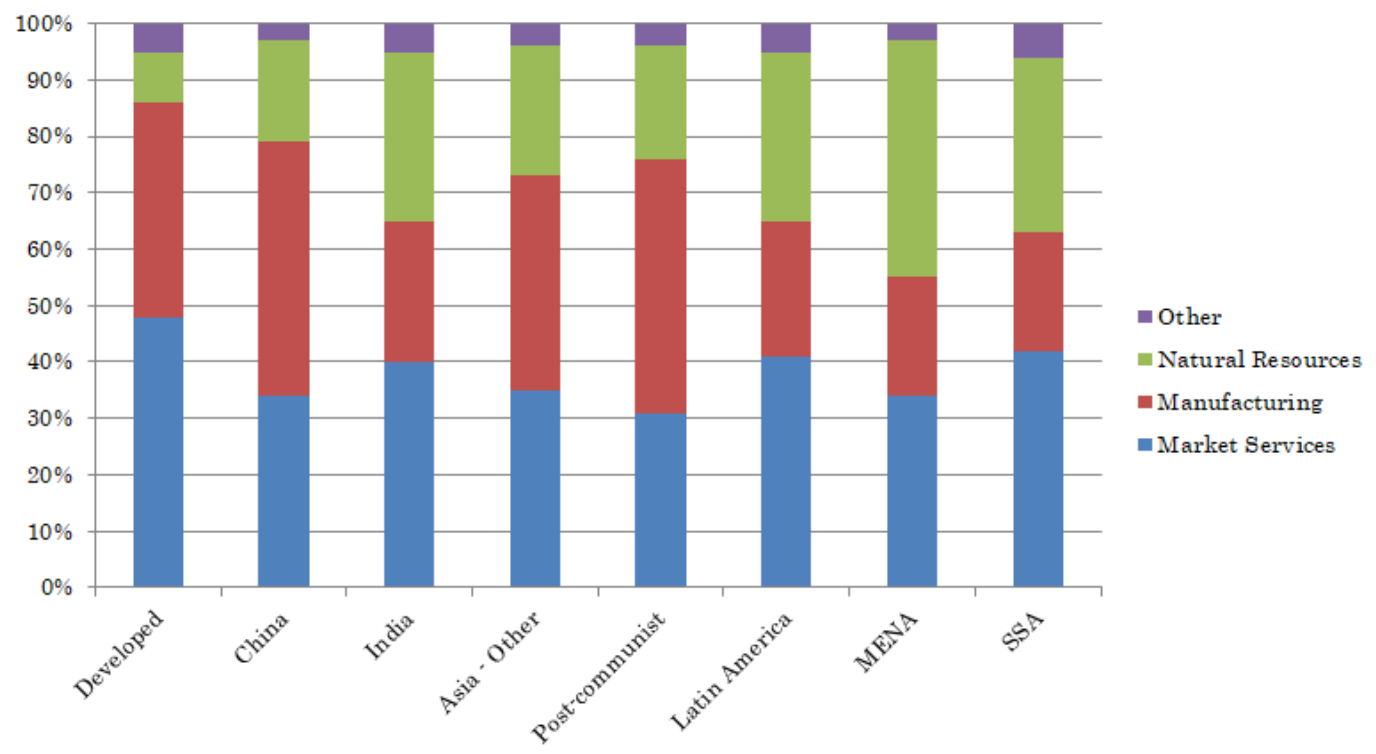

Figure 5: Growth of production for foreign markets broken down by sector, over 2001-2011 (per country group)

$$
\text { Source: Verspagen and Kaltenberg 2015 }
$$


A few scholars also provided new evidence on the classic hypothesis of manufacturing as the "engine of growth" (Szirmai 2012; Szirmai and Verspagen 2015; Haraguchi et al. 2017). Rodrik (2012) shows that the manufacturing sector exhibits unconditional convergence in labour productivity: the poorer a country is, the faster the productivity in its manufacturing sector will increase towards the technological frontier. Relative to other sectors, manufacturing has a higher potential for technological progress without being dependent on other country-specific conditions (Haraguchi et al., 2017) and it has traditionally absorbed significant quantities of unskilled labour, unlike mining activities (Rodrik, 2016). Furthermore, spillovers from learning associated with one technology are not automatically diffused to the whole economy, but tend to improve only similar technologies because of localized technological change (Atkinson and Stiglitz, 1969). Linkages between natural resource production and other sectors have historically been weaker than between manufacturing and the rest of the economy (Greenwald and Stiglitz, 2013), helping to explain the persistent large gap between the state of technology in the natural resource sector (mainly mining) and other sectors documented in Table 2.

Similar conclusions are reached using the notions of "complexity" and "product space" to guide empirical analyses (see the Chapter by Freire). First introduced by Hidalgo and Hausmann (2009), complexity rests on the idea of using the range of exported goods to proxy the technological and productive capabilities of a country. The concept has been refined by Tacchella et al. (2012) and Tacchella et al. (2013), who developed a complexity-weighted diversification index that they called Fitness. In practice, they consider that developed countries export most of the products, thus making the main information on products' complexity determined by the worst of its producers. For instance, a product that is produced by some scarcely competitive countries will have a low complexity, while the opposite will be true for products that only few developed countries produce. Therefore, a reasonable measure of country fitness or competitiveness (what we labelled $X_{i}$ in Eq. 2) will be given by the sum of all the products of the export basket weighted by their complexity 19 The notion of fitness is thus well in tune with how we defined competitiveness, and its microfoundations are akin to our "qualities of specialization": that is, the type and properties of exported products concur to determine income and growth rates, as showed by many empirical papers (Hausmann et al. 2007; Hidalgo and Hausmann 2009; Tacchella et al. 2012). This literature also find confirmation to the

\footnotetext{
${ }^{19}$ In recent papers, both Hidalgo (Albeaik et al. 2017) and Hausmann (Brummitt et al. 2018) have proposed new versions of their original complexity index. Still, their new work adds very little to the Fitness Index, and it seems a useless rediscovery of the work by Tacchella et al. (2012) and Tacchella et al. (2013) (see Pietronero et al. 2017 for a discussion).
} 
contention of Dosi et al. (1990) that absolute advantages determined by technological capabilities are the fundamental determinant of countries' participation to international trade. Advanced countries are found to export also products for which they do not possess a comparative advantage, contrarily to what Ricardo would have predicted. In general, comparative advantage theory is found working only for developing countries, whose export basket is limited to a handful of products. This asymmetry shows the relevance of diversification ( $\overline{\text { Hidalgo and Hausmann, } 2009)}$ and its advantage over Ricardian specialization (Tacchella et al., 2013); however, diversification is a luxury only available for countries that possess the necessary productive capabilities (Bahar and Santos, 2018).

\subsection{Is This Time Different? What China can Teach to Latin America}

Despite this dismal overview, some exceptions to the common pattern exist. Globalization did not harm the East Asia Tigers, which kept growing and industrializing at a satisfactory pace. This is partly explained by their overall defiance of the Washington Consensus prescriptions that led them to retain a wide range of heterodox policies (Cimoli et al., 2009a). These examples show the importance of staging and gradual opening to international trade according to the specific needs of each economy. On average, countries that managed to keep in place their trade and industrial policies achieved successful development performances, China being the obvious example. Indeed, the last three decades witnessed an impressive growth of the Chinese economy (Yao, 2014). China undertook a deep and fast structural transformation leading from a traditional and mostly rural economy to an economy driven by industrial activities. It is fair to say that China has been able to enormously profit from globalization, and it is now its fiercer advocate (New York Times 2017; Lund and Tyson 2018) .

The causes of this success are manifold. In primis, China has adopted a gradualist approach of economic reform and market opening (Yu et al., 2015). Chinese firms entered the global markets only after several decades of protection and capabilities accumulation, avoiding the negative Reinert-Vanek effect of sudden international competition. Reforms had a "dualistic nature", where a separate exportpromoting regime was created alongside the existing regime of import-substitution (Harrison, 2014). Secondly, China has been using a whole range of industrial policies and direct state interventions to govern its industrialization (see Dahlman 2009, for a throughout analysis). Those have entailed controls of FDIs, establishment of special export-processing zones amidst diffused protectionism, local content requirements, the establishment of heavily subsidized State-owned enterprises and massive investments in education and training. With reference to trade policy, tariffs have been generally high and consistently biased towards export-oriented sectors (Harrison, 2014). Furthermore, China has 
Table 3: Exports of primary products as a share of total exports for the main Latin American economies

\begin{tabular}{lccccccccc}
\hline & 1975 & 1980 & 1985 & 1990 & 1995 & 2000 & 2005 & 2010 & 2017 \\
\hline & & & & & & & & & \\
Argentina & 75.6 & 76.9 & 78.6 & 70.9 & 66.1 & 67.5 & 69.2 & 66.8 & 71.2 \\
Brazil & 74.7 & 62.8 & 56.3 & 48.1 & 46.5 & 41.6 & 47.0 & 63.4 & 62.4 \\
Chile & 90.0 & 90.9 & 93.1 & 88.7 & 86.5 & 83.8 & 84.9 & 87.4 & 85.9 \\
Colombia & 79.1 & 80.4 & 83.1 & 74.9 & 65.2 & 67.5 & 64.2 & 76.1 & $\ldots$ \\
Mexico & 68.9 & 88.1 & 72.9 & 56.5 & 22.3 & 16.5 & 22.9 & 24.0 & 17.9 \\
Peru & 97.1 & 83.2 & 88.0 & 81.6 & 85.2 & 77.6 & 82.6 & 86.3 & 88.6 \\
Uruguay & 70.0 & 62.1 & 65.0 & 61.2 & 61.2 & 58.1 & 68.1 & 74.0 & 79.8 \\
\hline
\end{tabular}

Source: ECLAC-CEPALSTAT Database

institutionalized the policy of emulation of foreign technologies by means of a deliberately lax IPRs regime (Reinert 2009; Dahlman 2009). Recent microeconometric evidence confirms this view, locating the roots of the Chinese manufacturing catching-up into "creative restructuring" and accumulation of absorptive capabilities by domestic firms, rather than sheer "creative destruction" fostered by globalized markets (Yu et al. 2015, Dosi et al. 2017). Chinese enterprises were thus able to move beyond labour cost advantages and gradually improved their international competitiveness through a mix of technology imports and increasing endogenous learning.

The Chinese example offers an interesting model for economies not yet industrialized, especially when compared with the opposite trajectory of Latin America 20 Castaldi et al. (2009) discuss the Latin America performance after the liberal reforms of the 1980s and show how almost the whole region ended up caught in a "low growth trap". Indeed, after the sudden opening of their economies, many Latin American countries saw an increase of the income elasticity of the demand for imports, which was not matched by an equal increase of exporting activities (Cimoli et al., 2009b). Cimoli and Correa (2005) show how Latin American economies have changed their specialization according to their factor endowments, namely cheap labour and natural resources. Over time, Latin America witnessed an increasing specialization in low-technology products and the emergence of a dualistic economy where only few firms were able to compete internationally (Cimoli and Katz 2003; Cimoli and Correa 2005). Table 3 provides evidence for some major countries in Latin America showing their persistent reliance on export of commodities, especially in recent years.

\footnotetext{
${ }^{20}$ At the same time, the very emergence of China as a major industrial player has profoundly changed the patterns of opportunities and constraints facing other economies (Kaplinsky and Morris, 2008). As an example, Coxhead (2007) argues that China's growth and globalization are likely to cause South-East Asian countries to experience negative termsof-trade shocks for labour-intensive manufactures, and positive shocks for primary products. Similar negative impacts on developed economies are increasingly documented within a growing strand of empirical research Autor et al. 2013. Pierce and Schott 2016).
} 
The impressive difference with the growth of China can be explained by the absence of careful industrial and trade policies that actively fostered the accumulation of technological capabilities in spite of comparative advantage (Lectard and Rougier, 2018).

\section{Conclusions and Implications for Policy}

In this chapter we have analysed the role played by endowment-based comparative advantages in international trade upon structural change. We began explaining what we meant with the term competitiveness, and its double meaning in terms of wealth creation and international trade performance. In turn, we highlighted how the latter feeds back into national income: exports and market shares influence macroeconomic levels of activity, employment and wages. In this perspective, technological absolute advantages are the main determinant of trade performance and predict countries' participation to international trade. Comparative advantages are only an ex-post synthetic measure of absolute productivity levels, and they might end up obscuring some economic dimensions of the phenomenon. The Dosi-Pavitt-Soete technology gap model (Dosi et al., 1990) allowed us to investigate adjustment mechanisms that go beyond sheer Ricardian efficiency. Indeed, a key determinant of country wealth is constituted by the kind of goods and sectors on which it specializes, which we characterized in terms of Keynesian and Schumpeterian efficiency.

Without appropriate policy interventions, countries tend to specialize according to their comparative advantages. Intra-country intersectoral differences in productivity and profitability trigger Ricardian adjustment processes that are comparative-advantage conforming. This is what happened during the last three decades of globalization: international demand for primary commodities has pushed resource-rich countries toward increasing specialization in their comparative advantages, as showed by the increasing weight of commodities in the production for foreign markets. On the technological front, innovative capabilities remain highly concentrated in the leading "technology club", with less developed countries still lagging behind. A notable exception is constituted by the rapid industrialization of China, but whose performance can be traced back to the implementation of a set of policies that stand in blatant contrast with the tenets of the Washington Consensus. Instead of simply conforming to the comparative advantage stemming from their given endowments, developing countries should put in place a wide array of trade and industrial policies that would foster the accumulation of technological capabilities. As the historical record shows, "getting Ricardo wrong" has been the single most important step toward industrialization and development. 
Simply correcting market failures while gradually upgrading the export structure in accordance to the given comparative advantage, as advocated by the "New structuralist approach" of Lin (2011), will hardly be sufficient. Lin's argument rests on the assumption that export diversification and sophistication both result from capital accumulation, which upgrades the factor endowment structure and over time shifts comparative advantage toward goods and industries that allow higher welfare. But as we have shown, the fallacies of this story reside in the characteristics of Ricardian adjustment processes, which by no means "naturally" lead to development. Quite the contrary: specialization in natural resources is historically associated with poverty and underdevelopment, and rarely followed by the needed growth-enhancing structural change. Many elements of comparative advantage are endogenous to policy choices (Stiglitz, 2011), so that attempts to escape poverty by openly defying comparative advantage should not be a taboo. Indeed, the results of Lectard and Rougier (2018) indicate that large benefits for the whole economy can be achieved by putting the transformation of the productive structure ahead of factor accumulation. The challenge should rather be avoiding that the targeted sectors become enclaves that do not deliver technological spillovers to the rest of the economy (Cimoli and Katz, 2003).

Today's developing nations lack the support of intellectuals like Hamilton or List: the consensus in the economic profession is still mostly in favour of deeper trade and financial integration at the international level (even though few would still defend the shock therapies of the original Washington Consensus) and very few voices are advocating changes that would leave LDCs the policy space to industrialize. We deem it difficult to reach a new consensus and set of policies for economic development without at the same time breaching the orthodoxy of the economic theory on trade, somewhat similarly to what Hamilton originally did when justifying the infant industry argument. The picture is complicated by the tendency of the new winners of globalization to join forces with developed countries in defending the merits of free trade (New York Times, 2017), despite their development being based on the blatant neglect of those same principles (Chang, 2002). On the technological side, the rapid pace at which manufacturing is merging with digital technologies (e.g. Lasi et al. 2014) is likely to become a further obstacle to industrialization for countries not possessing the necessary capabilities in ITC (Lund and Tyson, 2018) ${ }^{21}$ Policymakers in poor countries should employ all the policy space left by multilateral trade agreements to protect their strategic industries

\footnotetext{
${ }^{21}$ The more innovative end of the economy in recent years has been the development of so-called digital platforms (from Uber to Amazon and its Chinese counterpart, Alibaba). Many platforms by their very nature prove to be winner-take-all markets, in which only a handful of companies survive and are able to monopolize the global marketplace (Kenney and Zysman 2016). Entering those markets is proving difficult even for many advanced economies, and thus will pose a serious challenge for LDCs constrained in their policy space (Lund and Tyson, 2018).
} 
and nurturing specialization in dynamic sectors. Nevertheless, the existing regime might still end-up to be too tight, and in this case partial and ad hoc renegotiations might be necessary (Cimoli et al. 2009a). Without greater government involvements in designing the necessary catch-up policies we will hardly see many successful stories in the near future.

Quite surprisingly, the most recent critiques to the multilateral trade system are coming by the world technological leader, the United States (The Washington Post, 2018). Solid empirical research has documented the adverse labour consequences of Chinese competition (Autor et al. 2013, Pierce and Schott 2016), a finding that helps explain the recent comeback of protectionist policies in advanced economies. In particular, the Trump Administration has started imposing tariffs on imports (especially from China) with the stated aim of reducing the US trade deficit. The recent protectionist surge in the US has so far mainly targeted "old" industries, such as steel and aluminium New York Times, 2018). ${ }^{22}$ These hare hardly the industries from which the next technological paradigm is going to arise, and the potentiality of technological learning from them is very reduced for the USA. Note that the set of industrial and trade policies that we have been advocating should clearly be tailored to the level of development of each country. While for Latin America it might be a priority achieving structural transformation and building a strong manufacturing base, the strategic need of advanced countries like the USA is bound to be different. Rather, it seems that recent protectionism has been targeted to labour-intensive declining industries, with the aim of protecting jobs. This is consistent with the so-called "Australian case for protection" (Samuelson, 1981), a policy usually very costly but that at times can have positive welfare effects in imperfectly competitive sectors (Harrison, 1994). It might well be too soon to evaluate its overall welfare effects on the USA; however, we do think that the right set of policies for the technological leader should be focused on pushing ahead the endless frontier by means of innovation subsidies (Akcigit et al., 2018) and mission-oriented programs (Mazzucato 2013: Mowery 2012), rather than pouring resources on sunset industries. Also, the stickiness and the tacitness of much advanced technologies make technology transfer and international emulation second order concerns as long as the US keeps investing to retain the technological leadership; therefore, adopting a "techno-mercantilist" approach could not be warranted. We suggest that officials in the Trump Administration would find highly beneficial reading again the work done at the Berkeley Roundtable on the International Economy in the 1980s, when the same issues were discussed with reference to Japan (Zysman and Cohen, 1982).

\footnotetext{
${ }^{22}$ Plans of the Trump Administrations are to unilaterally expand tariffs on a large variety of investment and consumer goods in the near future if a deal with China will not be reached in the on-going negotiations.
} 
To conclude, our policy recommendations are still far from being a definitive set of practical policies for escaping the resource curse and the lock-in into comparative advantages. Nevertheless, we believe to have provided a theoretical framework capable to address the long-standing question posed by Joe Stiglitz: "is there any a priori reason why Switzerland should have a long-run comparative advantage in watches?". Overall, the evidence discussed suggests the continuing importance of the puzzles of Antonio Serra on the wealth of Venice vis-á-vis the poverty of Naples: indeed, it is technological learning and not endowments what will lead underdeveloped countries to become tomorrow's Venice. 


\section{References}

Abramovitz, M. (1986): "Catching up, forging ahead, and falling behind," The Journal of Economic History, 46, $385-406$.

Akcigit, U., S. T. Ates, And G. Impullitti (2018): "Innovation and Trade Policy in a Globalized World," NBER Working Paper No. 24543.

Akyuz, Y. (2009): "Industrial Tariffs, International Trade, and Development," in Industrial policy and development: The political economy of capabilities accumulation, Oxford: Oxford University Press.

Albeaik, S., M. Kaltenberg, M. Alsaleh, and C. A. Hidalgo (2017): "Improving the Economic Complexity Index," arXiv:1707.05826.

Allen, R. C. (2014): "American exceptionalism as a problem in global history," The Journal of Economic History, 74, $309-350$.

Amsden, A. H. (1989): Asia's next giant: South Korea and late industrialization, Oxford: Oxford University Press.

Atkinson, A. B. And J. E. Stiglitz (1969): “A new view of technological change,” The Economic Journal, 79, 573-578.

Autor, D., D. Dorn, And G. H. Hanson (2013): "The China syndrome: Local labor market effects of import competition in the United States," American Economic Review, 103, 2121-68.

Autor, D. H., D. Dorn, And G. H. Hanson (2016): "The china shock: Learning from labor-market adjustment to large changes in trade," Annual Review of Economics, 8, 205-240.

Auty, R. (1983): Sustaining development in mineral economies: the resource curse thesis, Routledge.

Bahar, D. And M. A. Santos (2018): "One more resource curse: Dutch disease and export concentration," Journal of Development Economics, 132, 102-114.

BAlassa, B. (1965): "Trade liberalisation and revealed comparative advantage," The Manchester School, 33, 99-123.

Baldwin, R. And P. Krugman (1988): "Industrial policy and international competition in wide-bodied jet aircraft," in Trade policy issues and empirical analysis, Chicago: University of Chicago Press, 45-78.

Bell, M. And K. PAvitT (1993): "Technological Accumulation and Industrial Growth: Contrasts Between Developed and Developing Countries," Industrial and Corporate Change, 2, 157-210.

Bernard, A. B., S. J. Redding, and P. K. Schott (2007): "Comparative advantage and heterogeneous firms," The Review of Economic Studies, 74, 31-66.

Bresnahan, T. F. And M. Trajtenberg (1995): "General purpose technologies Engines of growth?" Journal of Econometrics, 65, 83-108.

Brummitt, C. D., A. Gomez-Lievano, R. Hausmann, and M. H. Bonds (2018): "Machine-learned patterns suggest that diversification drives economic development," arXiv:1812.03534. 
Castaldi, C., M. Cimoli, N. Correa, And G. Dosi (2009): “Technological Learning, Policy Regimes and Growth: The Long Term Patterns and Some Specificities of a Globalized Economy," in Industrial Policy and Development the Political Economy of Capabilities Accumulation, Oxford: Oxford University Press.

Castellacci, F. (2008): "Technology clubs, technology gaps and growth trajectories," Structural Change and Economic Dynamics, 19, 301-314.

Castellacci, F. And D. Archibugi (2008): "The technology clubs: The distribution of knowledge across nations," Research Policy, 37, 1659-1673.

Chang, H.-J. (2002): Kicking away the ladder: development strategy in historical perspective, London: Anthem Press.

Chenery, H. B. (1960): "Patterns of industrial growth," American Economic Review, 50, 624-654.

Cimoli, M. (1988): "Technological Gaps and Institutional Asymmetries in a North-South Model with a Continuum of Goods," Metroeconomica, 39, 245-274.

Cimoli, M. And N. Correa (2005): "Trade Openness and Technology Gaps in Latin America: A Low-Growth Trap," in Beyond Reforms: Structural Dynamics and Macroeconomic Vulnerability, World Bank: Stanford University Press.

Cimoli, M. And G. Dosi (1995): "Technological paradigms, patterns of learning and development: an introductory roadmap," Journal of Evolutionary Economics, 5, 243-268.

Cimoli, M., G. Dosi, And J. Stiglitz (2009a): Industrial policy and development: The political economy of capabilities accumulation, Oxford University Press.

Cimoli, M. And J. Katz (2003): "Structural reforms, technological gaps and economic development: a Latin American perspective," Industrial and Corporate Change, 12, 387-411.

Cimoli, M., G. Porcile, And S. Rovira (2009b): "Structural change and the BOP-constraint: why did Latin America fail to converge?" Cambridge Journal of Economics, 34, 389-411.

CoAD, A. (2019): "Persistent heterogeneity of R\&D intensities within sectors: Evidence and policy implications," Research Policy, 48, 37-50.

Cohen, S. S. (1994): "Speaking freely," Foreign Affairs, 73, 194-197.

Coniglio, N. D., D. Vurchio, N. Cantore, And M. Clara (2018): "On the evolution of comparative advantage: path-dependent versus path-defying changes," SERIES Working Paper.

Corden, W. M. (1984): "Booming sector and Dutch disease economics: survey and consolidation," Oxford Economic Papers, 36, 359-380.

Corden, W. M. And J. P. NeARy (1982): "Booming sector and de-industrialisation in a small open economy," The Economic Journal, 92, 825-848.

Coxhead, I. (2007): "A new resource curse? Impacts of Chinas boom on comparative advantage and resource dependence in Southeast Asia," World Development, 35, 1099-1119. 
Dahlman, C. J. (2009): "Growth and development in China and India: the role of industrial and innovation policy in rapid catch-up," in Industrial policy and development: The political economy of capabilities accumulation, Oxford: Oxford University Press.

David, A. P. AND G. Wright (1997): "Increasing returns and the genesis of American resource abundance," Industrial and Corporate Change, 6, 203-245.

DAvid, P. A. (1985): "Clio and the Economics of QWERTY," American Economic Review, 75, 332-337.

Delgado, M., C. Ketels, M. E. Porter, And S. Stern (2012): "The determinants of national competitiveness," NBER Working Paper No. 18249.

DiaO, X., M. McMillan, And D. Rodrik (2017): "The Recent Growth Boom in Developing Economies: A Structural Change Perspective," NBER Working Paper No. 23132.

Dosi, G. (1982): “Technological paradigms and technological trajectories: a suggested interpretation of the determinants and directions of technical change," Research Policy, 11, 147-162.

(1988): "Sources, procedures, and microeconomic effects of innovation," Journal of Economic Literature, 11201171.

Dosi, G., C. Freeman, And S. FABiAni (1994): "The process of economic development: introducing some stylized facts and theories on technologies, firms and institutions," Industrial and Corporate Change, 3, 1-45.

Dosi, G., M. Grazzi, And D. Moschella (2015): "Technology and costs in international competitiveness: from countries and sectors to firms," Research Policy, 44, 1795-1814.

Dosi, G., R. Nelson, And S. Winter (2001): The nature and dynamics of organizational capabilities, Oxford: Oxford University Press.

Dosi, G. And R. R. Nelson (2010): "Technical change and industrial dynamics as evolutionary processes," Handbook of the Economics of Innovation, 1, 51-127.

Dosi, G., K. Pavitt, And L. Soete (1990): The economics of technical change and international trade, London: Harvester Wheatsheaf.

Dosi, G., X. YU, M. Grazzi, And J. Lei (2017): "Inside the virtuous circle between productivity, profitability, investment and corporate growth: An anatomy of Chinese industrialization," Research Policy, 46, 1020-1038.

EAton, J. And S. Kortum (2002): "Technology, geography, and trade," Econometrica, 70, 1741-1779.

(2012): "Putting Ricardo to work," Journal of Economic Perspectives, 26, 65-90.

FagerberG, J. (1988): "International competitiveness," The Economic Journal, 98, 355-374.

(1994): "Technology and international differences in growth rates," Journal of Economic Literature, 32, 11471175 . 
_ (1996): "Technology and competitiveness," Oxford Review of Economic Policy, 12, 39-51.

Fally, T. AND J. SAYRe (2018): “Commodity trade matters," NBER Working Paper No. 24965.

Flam, H. AND M. J. Flanders (1991): Heckscher-Ohlin trade theory, Cambridge (MA): MIT Press.

Freeman, C. (1987): Technology Policy and Economic Performance: Lessons from Japan, Pinter.

_ (1995): "The National System of Innovationin historical perspective," Cambridge Journal of Economics, 19, 5-24.

- (2004): "Technological infrastructure and international competitiveness," Industrial and Corporate Change, 13, $541-569$.

Freeman, C. AND F. LouÇÃ (2001): As time goes by: from the industrial revolutions to the information revolution, Oxford: Oxford University Press.

French, S. (2017): "Revealed comparative advantage: What is it good for?" Journal of International Economics, 106, $83-103$.

Gandolfo, G. (2013): International trade theory and policy, Springer Science \& Business Media.

Gerschenkron, A. (1962): Economic backwardness in historical perspective: a book of essays, Cambridge (MA): Harvard University Press.

Godin, B. (2004): "The obsession for competitiveness and its impact on statistics: the construction of high-technology indicators," Research Policy, 33, 1217-1229.

Greenwald, B. And J. E. Stiglitz (2013): "Industrial policies, the creation of a learning society, and economic development," in The Industrial Policy Revolution I, Springer, 43-71.

Grossman, G. M. And E. Helpman (1989): "Product development and international trade," Journal of Political Economy, 97, 1261-1283.

Hamilton, A. (1791): Reports of the Secretary of the Treasury on the Subject of Manufactures.

Hanlon, W. W. (2019): "The Persistent Effect of Temporary Input Cost Advantages in Shipbuilding, 1850-1911,” NYU Stern working paper.

Hanson, G. H., N. Lind, And M.-A. Muendler (2015): "The dynamics of comparative advantage," NBER Working Paper No. 21753.

Haraguchi, N., C. F. C. Cheng, and E. Smeets (2017): "The importance of manufacturing in economic development: Has this changed?" World Development, 93, 293-315.

Harding, T. And A. J. Venables (2016): "The implications of natural resource exports for nonresource trade," IMF Economic Review, 64, 268-302.

Harrison, A. (2014): "Trade and industrial policy," The Oxford Companion to the Economics of China, 161. 
Harrison, A. ANd A. Rodríguez-Clare (2010): "Trade, foreign investment, and industrial policy for developing countries," in Handbook of Development Economics, Elsevier, vol. 5, 4039-4214.

HARrison, R. (1994): "Trade and Industrial Policy for a "Declining" Industry: The Case of the US Steel Industry," in Empirical studies of strategic trade policy, Chicago: University of Chicago Press, 131-156.

Hausmann, R., J. Hwang, And D. Rodrik (2007): "What you export matters," Journal of Economic Growth, 12, $1-25$.

HEAD, K. (1994): "Infant industry protection in the steel rail industry," Journal of International Economics, 37, $141-165$.

Heckscher, E. F. (1919): The effect of foreign trade on the distribution of income.

Herrendorf, B., R. Rogerson, And A. Valentinyi (2014): "Growth and structural transformation," in Handbook of Economic Growth, Elsevier, vol. 2, 855-941.

Hidalgo, C. A. And R. Hausmann (2009): "The building blocks of economic complexity," Proceedings of the National Academy of Sciences, 106, 10570-10575.

Hirschman, A. O. (1958): The strategy of economic development, New Haven: Yale University Press.

Jacks, D. S., K. H. O’Rourke, And J. G. Williamson (2011): "Commodity price volatility and world market integration since 1700," Review of Economics and Statistics, 93, 800-813.

James, A. (2015): "The resource curse: A statistical mirage?" Journal of Development Economics, 114, 55-63.

Jones, C. I. (2016): "The facts of economic growth," in Handbook of Macroeconomics, Elsevier, vol. 2, 3-69.

JuhÁsz, R. (2018): "Temporary protection and technology adoption: Evidence from the napoleonic blockade," American Economic Review, 108, 3339-76.

Kalouptsidi, M. (2017): "Detection and impact of industrial subsidies: The case of Chinese shipbuilding," The Review of Economic Studies, 85, 1111-1158.

KAPlinsky, R. AND M. Morris (2008): "Do the Asian drivers undermine export-oriented industrialization in SSA?" World Development, 36, 254-273.

Kemp, M. C. AND N. VAN Long (1984): "The role of natural resources in trade models," Handbook of International Economics, 1, 367-417.

Kenney, M. And J. Zysman (2016): "The rise of the platform economy," Issues in Science and Technology, 32, 61.

Krugman, P. (1979): "Increasing returns, monopolistic competition, and international trade," Journal of International Economics, 9, 469-479.

(1980): "Scale economies, product differentiation, and the pattern of trade," American Economic Review, 70, 950-959. 
(1987): "The narrow moving band, the Dutch disease, and the competitive consequences of Mrs. Thatcher: Notes on trade in the presence of dynamic scale economies," Journal of Development Economics, 27, 41-55.

— (1994): "Competitiveness: a dangerous obsession," Foreign Affairs, 73, 28.

Kuznets, S. (1966): Modern economic growth, New Haven: Yale University Press.

- (1973): "Modern economic growth: findings and reflections," American Economic Review, 63, 247-258.

LANE, N. (2017): "Manufacturing revolutions. Industrial Policy and Networks in South Korea," working paper.

Lasi, H., P. Fettke, H.-G. Kemper, T. Feld, And M. Hoffmann (2014): "Industry 4.0," Business E Information Systems Engineering, 6, 239-242.

Laursen, K. And V. Meliciani (2002): "The relative importance of international vis-à-vis national technological spillovers for market share dynamics," Industrial and Corporate Change, 11, 875-894.

Lectard, P. And E. Rougier (2018): "Can developing countries gain from defying comparative advantage? Distance to comparative advantage, export diversification and sophistication, and the dynamics of specialization," World Development, 102, 90-110.

Lin, J. Y. (2011): "New Structural Economics: A Framework for Rethinking Development," The World Bank Research Observer, 193-221.

List, F. (1841): The National System of Political Economy.

Lund, S. And L. Tyson (2018): "Globalization Is Not in Retreat: Digital Technology and the Future of Trade," Foreign Affairs, 97, 130 .

MacDonald, G. M. And J. R. Markusen (1985): "A rehabilitation of absolute advantage," Journal of Political Economy, 93, 277-297.

Malerba, F. (2002): "Sectoral systems of innovation and production," Research policy, 31, 247-264.

Martinelli, A. (2012): "An emerging paradigm or just another trajectory? Understanding the nature of technological changes using engineering heuristics in the telecommunications switching industry," Research Policy, 41, 414-429.

MAtsuYAma, K. (1992): "Agricultural productivity, comparative advantage, and economic growth," Journal of Economic Theory, 58, 317-334.

Mazzucato, M. (2013): The entrepreneurial state: Debunking public vs. private sector myths, London: Anthem Press.

McMillan, M. AND D. RodRIK (2011): "Globalization, structural change and productivity growth," in Making globalization socially sustainable, International Labour Organization and World Trade Organization, 49-84.

McMillan, M., D. Rodrik, And Í. Verduzco-Gallo (2014): "Globalization, structural change, and productivity growth, with an update on Africa," World Development, 63, 11-32. 
Melitz, M. J. (2003): "The impact of trade on intra-industry reallocations and aggregate industry productivity," Econometrica, 71, 1695-1725.

Melitz, M. J. And D. Trefler (2012): "Gains from trade when firms matter," Journal of Economic Perspectives, 26, 91-118.

Mowery, D. C. (2012): "Defense-related R\&D as a model for Grand Challenges technology policies," Research Policy, 41, 1703-1715.

Mulatu, A. (2016): "On the concept of 'competitiveness' and its usefulness for policy," Structural Change and Economic Dynamics, 36, 50-62.

Nelson, R. R. AND H. PACK (1999): "The Asian miracle and modern growth theory," The Economic Journal, 109, $416-436$.

Nelson, R. R. And B. SAmpat (2001): "Making sense of institutions as a factor shaping economic performance," Journal of Economic Behavior \& Organization, 44, 31-54.

New York Times, . (2017): "In Era of Trump, China's President Champions Economic Globalization," retrieved at: https://www.nytimes.com/2017/01/17/business/dealbook/world-economic-forum-davos-china-xi-globalization.html.

(2018): "Trump Hits China With Stiff Trade Measures," retrieved at: https://www.nytimes.com/2018/03/22/us/politics/trump-will-hit-china-with-trade-measures-as-white-house-exemptsallies-from-tariffs.html.

OhLin, B. (1933): International and interregional trade, Cambridge (MA): Harvard University Press.

PAvitT, K. (1984): "Sectoral patterns of technical change: towards a taxonomy and a theory," Research Policy, 13, $343-373$.

(1987): "The objectives of technology policy," Science and Public Policy, 14, 182-188.

Pierce, J. R. And P. K. Schott (2016): "The surprisingly swift decline of US manufacturing employment," American Economic Review, 106, 1632-62.

Pietronero, L., M. Cristelli, A. Gabrielli, D. Mazzilli, E. Pugliese, A. Tacchella, and A. Zaccaria (2017): "Economic Complexity: "Buttarla in caciara" vs a constructive approach," arXiv:1709.05272.

Pisano, G. P. And W. C. Shin (2012): Producing prosperity: Why America needs a manufacturing renaissance, Cambridge (MA): Harvard Business Press.

Porter, M. E. (1990): "The Competitive Advantage of Nations," Harvard Business Review.

REINERT, E. (2009): "Emulation vs. comparative advantage: competing and complementary principles in the history of economic policy," in Industrial policy and development: The political economy of capabilities accumulation, Oxford: Oxford University Press. 
Reinert, E. S. (1995): "Competitiveness and its predecessorsa 500-year cross-national perspective," Structural Change and Economic Dynamics, 6, 23-42.

(1996): "The facts of economic growth," in International Trade Regulation, National Development Strategies and the Environment: Towards Sustainable Development?, Oslo: Centre for Development and the Environment.

(1999): "The role of the state in economic growth," Journal of Economic Studies, 26, 268-326.

(2007): How rich countries got rich and why poor countries stay poor, Constable.

RiCARDo, D. (1817): On the principles of political economy and taxation.

Rodrik, D. (2006): “Goodbye Washington consensus, hello Washington confusion? A review of the World Bank's economic growth in the 1990s: learning from a decade of reform," Journal of Economic Literature, 44, 973-987.

(2012): "Unconditional convergence in manufacturing," The Quarterly Journal of Economics, 128, 165-204.

(2016): "Premature deindustrialization," Journal of Economic Growth, 21, 1-33.

SACHS, J. D. AND A. M. WARner (1995): "Natural resource abundance and economic growth," NBER Working Paper No. 5398

(2001): "The curse of natural resources," European Economic Review, 45, 827-838.

Samuelson, P. A. (1981): "Summing up on the Australian Case for Protection," The Quarterly Journal of Economics, $96,147-160$.

- (2004): "Where Ricardo and Mill rebut and confirm arguments of mainstream economists supporting globalization," Journal of Economic Perspectives, 18, 135-146.

Serra, A. (1613): Breve trattato delle cause che possono far abbondare li regni d'oro e d'argento dove non sono miniere, Napoli: Lazzaro Scoriggio.

Serra, N. And J. E. Stiglitz (2008): The Washington consensus reconsidered: Towards a new global governance, Oxford: Oxford University Press.

Smith, A. (1776): An Inquiry into the Nature and Causes of the Wealth of Nations.

Srholec, M. And B. Verspagen (2012): "The Voyage of the Beagle into innovation: explorations on heterogeneity, selection, and sectors," Industrial and Corporate Change, 21, 1221-1253.

Stiglitz, J. E. (2011): "Rethinking development economics," The World Bank Research Observer, 26, 230-236.

Stiglitz, J. E. And B. C. Greenwald (2014): Creating a learning society: A new approach to growth, development, and social progress, New York: Columbia University Press.

Syrquin, M. (1988): "Patterns of structural change," Handbook of Development Economics, 1, $203-273$.

Szirmai, A. (2012): "Industrialisation as an engine of growth in developing countries, 1950-2005," Structural Change and Economic Dynamics, 23, 406-420. 
Szirmai, A. AND B. Verspagen (2015): "Manufacturing and economic growth in developing countries, 1950-2005," Structural Change and Economic Dynamics, 34, 46-59.

Tacchella, A., M. Cristelli, G. Caldarelli, A. Gabrielli, and L. Pietronero (2012): "A new metrics for countries' fitness and products' complexity," Scientific Reports, 2, 723.

(2013): "Economic complexity: conceptual grounding of a new metrics for global competitiveness," Journal of Economic Dynamics and Control, 37, 1683-1691.

The Washington Post, . (2018): "Will Trump Finally Turn His Trade Guns on the WTO?" retrieved at: https://www.washingtonpost.com/business/will-trump-finally-turn-his-trade-guns-on-the-wto/2018/08/30/.

Thurow, L. C. (1994): "Microchips, not potato chips," Foreign Affairs, 73, 189-192.

Torvik, R. (2009): "Why do some resource-abundant countries succeed while others do not?" Oxford Review of Economic Policy, 25, 241-256.

Tyson, L. D. (1993): Who's bashing whom?: trade conflict in high-technology industries, Peterson Institute.

VAn Der Ploeg, F. (2011): "Natural resources: curse or blessing?" Journal of Economic Literature, 49, 366-420.

Venables, A. J. (2016): “Using natural resources for development: why has it proven so difficult?" Journal of Economic Perspectives, 30, 161-84.

Verspagen, B. And M. Kaltenberg (2015): "Catching-up in a globalised context: Technological change as a driver of growth," UNIDO-MERIT Working Papers.

Wright, G. (1997): "Towards a more historical approach to technological change," The Economic Journal, 107, 15601566.

YAO, Y. (2014): "The Chinese growth miracle," in Handbook of Economic Growth, Elsevier, vol. 2, 943-1031.

Yu, X., G. Dosi, J. Lei, And A. Nuvolari (2015): "Institutional change and productivity growth in Chinas manufacturing: the microeconomics of knowledge accumulation and creative restructuring," Industrial and Corporate Change, $24,565-602$.

Zysman, J. And S. S. Cohen (1982): "Double or nothing: open trade and competitive industry," Foreign Affairs, 61, 1113. 